\title{
Rethinking pioglitazone as a cardioprotective agent: a new perspective on an overlooked drug
}

\author{
Lorenzo Nesti ${ }^{1,2^{*}} \mathbb{D}$, Domenico Tricò ${ }^{1,3}$, Alessandro Mengozzi ${ }^{4}$ and Andrea Natali ${ }^{1,2}$
}

\begin{abstract}
Since 1985, the thiazolidinedione pioglitazone has been widely used as an insulin sensitizer drug for type 2 diabetes mellitus (T2DM). Although fluid retention was early recognized as a safety concern, data from clinical trials have not provided conclusive evidence for a benefit or a harm on cardiac function, leaving the question unanswered. We reviewed the available evidence encompassing both in vitro and in vivo studies in tissues, isolated organs, animals and humans, including the evidence generated by major clinical trials. Despite the increased risk of hospitalization for heart failure due to fluid retention, pioglitazone is consistently associated with reduced risk of myocardial infarction and ischemic stroke both in primary and secondary prevention, without any proven direct harm on the myocardium. Moreover, it reduces atherosclerosis progression, in-stent restenosis after coronary stent implantation, progression rate from persistent to permanent atrial fibrillation, and reablation rate in diabetic patients with paroxysmal atrial fibrillation after catheter ablation. In fact, human and animal studies consistently report direct beneficial effects on cardiomyocytes electrophysiology, energetic metabolism, ischemia-reperfusion injury, cardiac remodeling, neurohormonal activation, pulmonary circulation and biventricular systo-diastolic functions. The mechanisms involved may rely either on anti-remodeling properties (endothelium protective, inflammation-modulating, anti-proliferative and anti-fibrotic properties) and/or on metabolic (adipose tissue metabolism, increased HDL cholesterol) and neurohormonal (renin-angiotensin-aldosterone system, sympathetic nervous system, and adiponectin) modulation of the cardiovascular system. With appropriate prescription and titration, pioglitazone remains a useful tool in the arsenal of the clinical diabetologist.
\end{abstract}

Keywords: Type 2 diabetes, Cardiovascular, Pharmacologic effects, PPARs, Pioglitazone, Cardiovascular risk factors, Cardiovascular prevention, Clinical management, Cardioprotection, Heart failure

\section{Introduction}

Early after their approval for the treatment of type 2 diabetes (T2D) in 1985, the insulin-sensitizing agents thiazolidinediones (TDZs) pioglitazone, rosiglitazone and troglitazone displayed alleged safety concerns about fluid retention, increased risk of developing heart failure

\footnotetext{
*Correspondence: Iorenzo.nesti@phd.unipi.it

1 Metabolism, Nutrition, and Atherosclerosis Laboratory, Department

of Clinical and Experimental Medicine, University of Pisa, Via Savi 10, 56126 Pisa, Italy

Full list of author information is available at the end of the article
}

(HF), ischemic heart disease, and liver toxicity -not all substantiated by later observations-, determining troglitazone and rosiglitazone withdrawal and subsequent reinstatements [1]. Moreover, concerns related to potential adverse effects of pioglitazone, including weight gain, bladder cancer and decreased bone mineral density with increased risk of fractures, have led to a progressive and sustained decline in pioglitazone prescriptions [2-4]. Nevertheless, treatment with pioglitazone is still available in most countries, is cost-effective, and has gained renewed popularity after novel favorable evidence [5, 
6]. Especially after the discovery of the cardioprotective effects of sodium-glucose cotransporter (SGLT-2) inhibitors and glucagon-like peptide (GLP)-1 receptor agonists [7], the T2D treatment paradigm has faced a Copernican revolution, now also focusing on non-glycemic, cardioprotective effects of glucose-lowering agents -including the oldest ones [8]. Despite the initial aversion due to increased HF risk, several studies have examined the complex metabolic and biological roles of pioglitazone in many cardiovascular diseases. Experimental and human data suggest beneficial effects on the vascular system, including delayed atherosclerosis progression and reduced cardiovascular events [9]. Although pioglitazone might worsen HF by inducing sodium-water retention and oedema, there are some counterarguments [10] : first, it does not increase mortality due to HF, second, it has no detectable deleterious effect on the heart [11, $12]$. On the contrary, it positively modulates several cardiac and vascular functions, as well as some cardiovascular risk factors, either directly or indirectly through its main target peroxisome proliferator-activated receptor- $\gamma$ (PPAR- $\gamma$ ), as it will be later clarified. The non-negligible degree of uncertainty about the safety and the exact effects of pioglitazone on the cardiovascular system, both in research and in everyday clinical practice, makes it a very current topic. This is particularly relevant in a worldwide environment where cardiovascular diseases and "diabesity" are the 21st century leading pandemic, with a very high economic impact on the healthcare systems.

To clarify this issue, we reviewed the available literature on the cardiac and vascular effects of pioglitazone, encompassing both in vitro and in vivo studies in experimental animals and humans, as well as the evidence generated by major randomized clinical trials (RCTs), to condensate and critically evaluate the evidence for an aware clinical use of pioglitazone.

\section{Pioglitazone and major cardiovascular outcomes: revision of major clinical trials and meta-analyses from the clinician's point of view \\ Atherosclerosis-related events}

Growing evidence suggests a strong protective effect of pioglitazone on atherosclerosis-driven events of either cardiac or cerebrovascular nature. Already in 2005, the PROactive trial enlightened the role of pioglitazone in reducing by $16 \%$ the composite risk of all-cause mortality, non-fatal myocardial infarction, and stroke in T2D patients at high risk of macrovascular events (HR $0.84,95 \%$ CI $0.72-0.98$ ) [13]. In the last years, this once underrated result gained increasing attention as several observations pointed out the protective cardiovascular effect of pioglitazone in different clinical settings. In
2017, a meta-analysis of 9 RCTs in individuals with and without CVD ( $\mathrm{n}=12,026)$ showed that pioglitazone reduced the risk of major adverse cardiovascular events (MACE, composite of non-fatal myocardial infarction, non-fatal stroke and cardiovascular death) both in pre-diabetic/insulin resistant subjects by $23 \%(0.77$, $0.64-0.93)$ and in diabetic patients by $17 \%(0.83,0.72-$ 0.97) [14]. These results were confirmed by another meta-analysis of $10 \mathrm{RCTs}$ in patients with established cardiovascular disease (CVD) $(\mathrm{n}=10,095)$ wherein pioglitazone reduced recurrent MACE by an impressive $26 \%(0.94,0.69-0.92)$ [15]. Last year, an all-encompassing meta-analysis of 26 RCTs $(n=19,645)$, including results from the studies TOSCA.IT [6], PPAR [16], and PRIDE [17] and run on a population composed of both diabetics and pre-diabetics and with different $\mathrm{CV}$ risk, confirmed a $20 \%$ reduction in the risk of MACE $(0.80$, 0.71-0.89) [18]. A similar risk reduction was seen for two individual MACE components, non-fatal myocardial infarction (20\%: $0.80,0.64-0.95)$ and non-fatal stroke (19\%: 0.81, 0.67-0.94), whereas cardiovascular death (4\%: 0.96, 0.74-1.18) and all-cause mortality (3\%: 0.97, 0.80-1.14) seemed not affected. In subgroup analyses, the cardiovascular protective effects of pioglitazone were confirmed in patients with pre-diabetes $(0.8,0.6-0.9)$ and diabetes $(0.8,0.7-1.0)$. The benefit of pioglitazone was consistently greater in secondary than primary prevention (Fig. 1); however, group differences between patients with and without established CVD were not statistically significant.

Notably, SGLT-2 inhibitors and GLP-1 receptor agonists, which are now acknowledged as the best novel therapies targeting both diabetes and cardiovascular risk, showed a similar magnitude of the effect in reducing MACE by $14 \%$ with a HR of 0.86 SGLT-2 inhibitors $[19,20]$ (though for canagliflozin was not significant [21] and by $16 \%$ that is 0.74 to 0.88 for GLP1 receptor agonists $[22,23]$. A recent comprehensive umbrella metaanalysis confirmed this point [24]. Although the use of the HR is not free from biases [25], these data show that he effects size of MACE reduction obtained with pioglitazone therapy is comparable to the one observed with the newer (and more expensive-for both the patient and the healthcare system) drugs that recently revolutionized the approach to T2D. With appropriate prescription and titration, this would make of pioglitazone a cost-effective cardioprotective agent in the arsenal of the clinical diabetologist. The aim of the present work is neither to redo a metanalysis nor to systematically review all the studies on cardiovascular outcomes with pioglitazone, which can be found elsewhere; we acknowledge that this is a limit of this manuscript. Our aim is to highlight the effect size of MACE reduction obtained with pioglitazone with a 


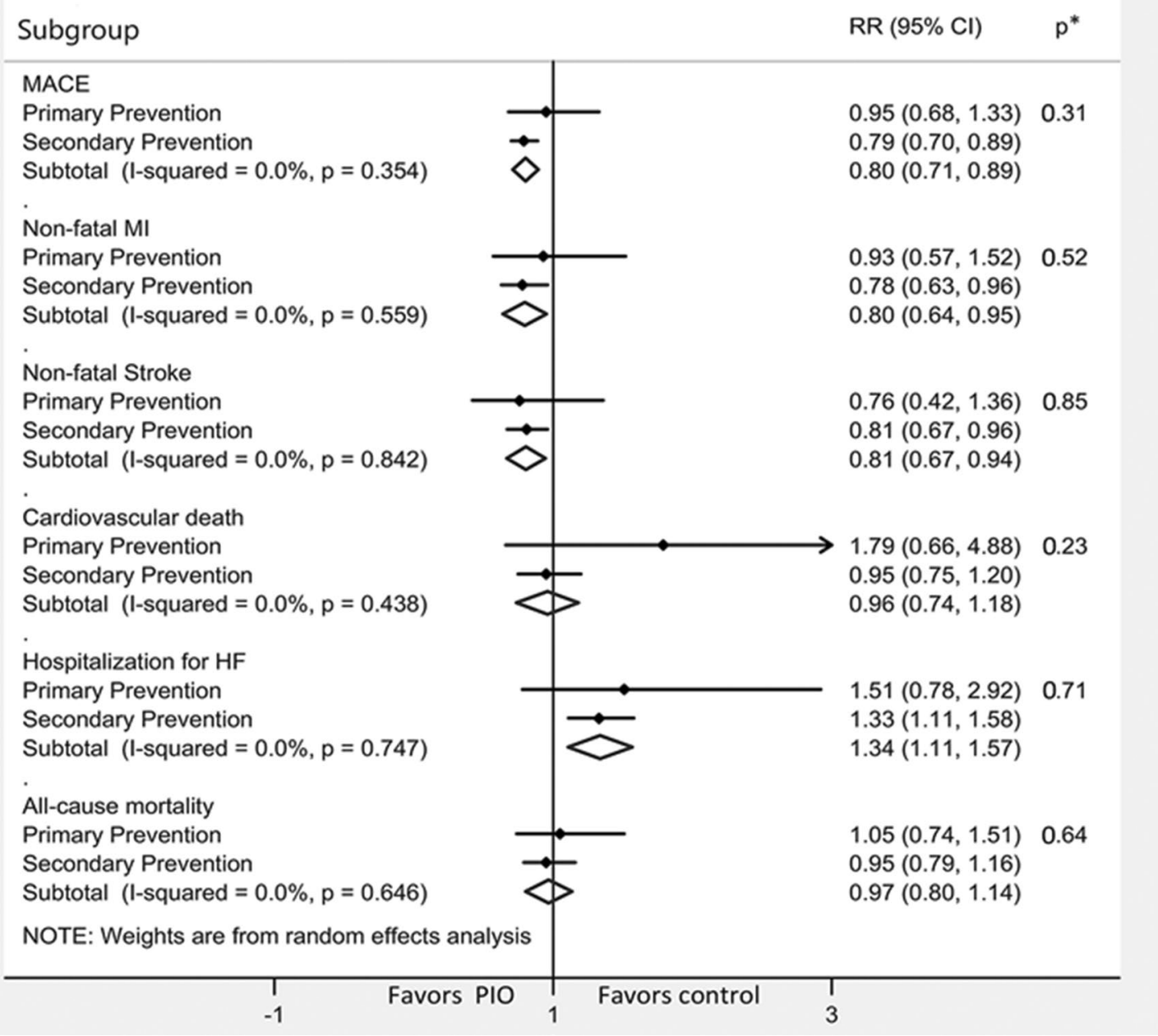

Fig. 1 Effects of pioglitazone on cardiovascular endpoints. Metanalysis subgroup analysis on pioglitazone trials on major adverse cardiovascular events (MACE) by primary and secondary prevention. Pioglitazone is associated with a reduction in overall MACE, non-fatal myocardial infarct, and non-fatal stroke, while having a neutral effect on cardiovascular death and all-cause mortality. In overt heart failure, conversely, it is associated with an increase in the risk of hospitalization. Modified with permission from Zhou Y et al. [18]. $p^{*}=p$ for heterogeneity between subgroups

clinical-oriented point of view to help the clinician take aware and critical decisions.

\section{Heart failure}

Large RCTs, including the PROactive [13, 26], RECORD [27], and ADOPT [28] trials, showed an increased hospitalization rate for HF associated with pioglitazone or rosiglitazone treatment. However, in the recent IRIS trial [12] and in a large populationbased Asian cohort [29], no difference emerged in the rate of hospitalization for HF among people at low-risk of HF, with proper clinical surveillance and dose titration of pioglitazone treatment. Consistently, a recent meta-analysis confirmed an increased risk of incident $\mathrm{HF}$ in patients treated with pioglitazone $(1.34,1.11-$ 1.57), which however appeared limited to those with established CVD (Fig. 1) [18]. These observations suggest that pioglitazone may exacerbate HF particularly in patients with multiple risk factors and/or suffering from subclinical HF. The predominant mechanism, which will be discussed below, may be volume expansion due to renal fluid retention, without alterations in cardiac function or structure [14]. According to this evidence, the current guidelines from the American Diabetes Association (ADA) [30] and the American Heart Association (AHA) [31] recommend that 
pioglitazone should be used cautiously in patients with symptomatic HF or at risk of acute decompensated HF.

\section{Effects of pioglitazone on the heart}

The effects on cardiovascular outcomes shown by pioglitazone rely on mechanisms that remain largely unknown. The polyhedric effects exerted by this drug can be understood by looking at its main pharmacological target, the nuclear receptor PPAR- $\gamma$, a complex transcription factor that is present in almost all tissues and modulates delicate metabolic, inflammatory, and proliferative pathways. Also, PPAR- $\gamma$ independent mechanisms have been proposed as well, further amplifying the potential cardioactive effects of pioglitazone. The effects of pioglitazone on the heart are schematized in Fig 2.

\section{Left ventricular systolic and diastolic functions Human studies}

A relevant increase in LV ejection fraction (LVEF) and stroke volume was reported in both T2D patients and normal glucose tolerant subjects after 24 weeks of pioglitazone treatment [32], and a borderline increase in LVEF was observed in 30 diabetic patients after 26 weeks of treatment alike [33]. Another study on 24 diabetic subjects randomized to either pioglitazone or placebo confirmed an improvement in stroke volume and LVEF with pioglitazone [34]. With the exception of one study in 88 diabetic patients, which reported no change in diastolic indices with pioglitazone [35], numerous other works on subjects with preserved systolic function reported consistent improvements in diastolic function with amelioration of early-to-atrial mitral flow (E/A) ratio, improvement in tissue Doppler values such as $E / \mathrm{e}^{\prime}$ and other diastolic parameters, irrespective of the presence of

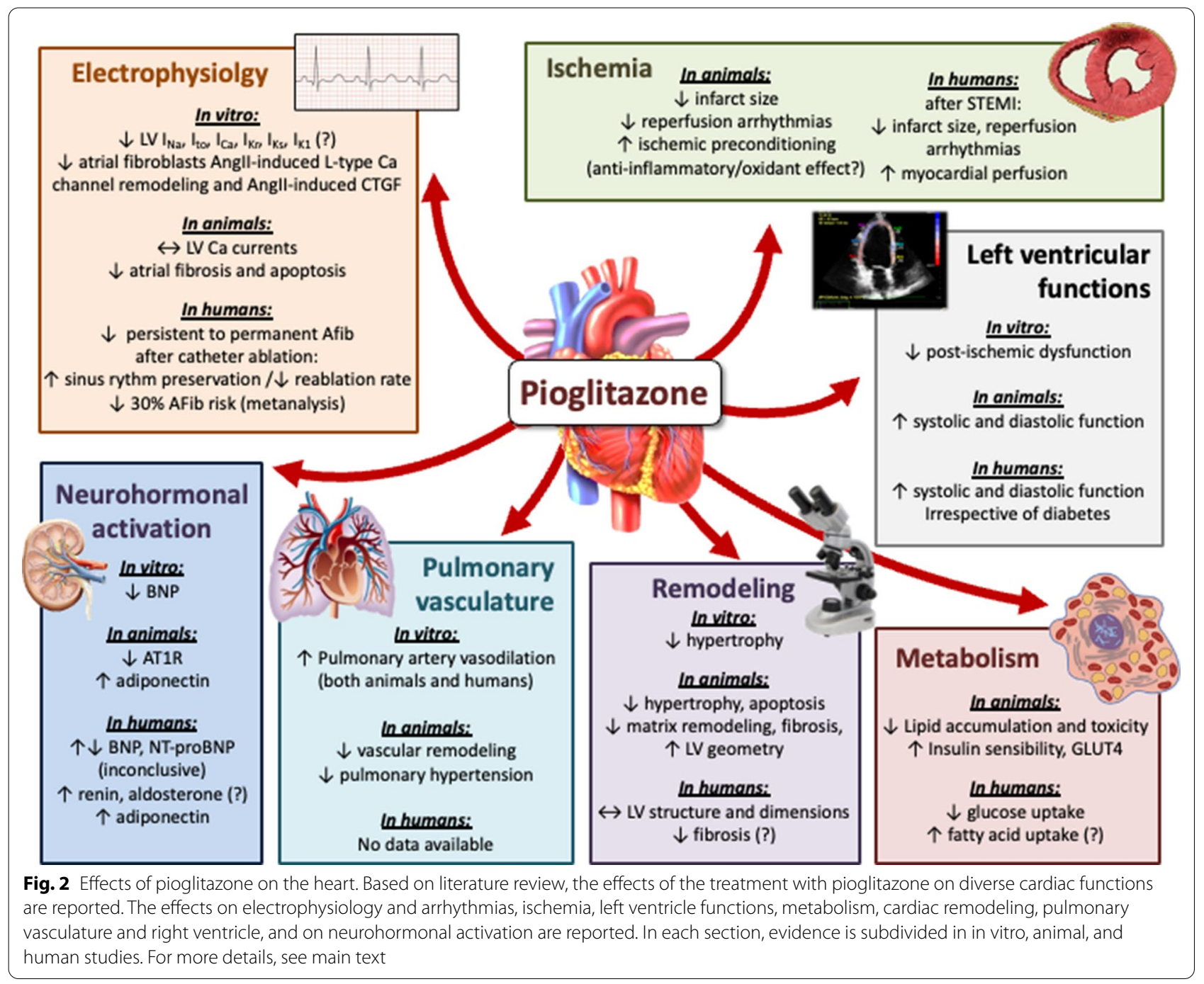


hypertension, diabetes, and/or diastolic dysfunction [17, 34, 36-41].

\section{Animal studies}

Concordantly with human observations, pioglitazone reduced LV diastolic and systolic dimensions, together with improved contractility in diabetic [42] and nondiabetic murine models [43, 44]. Also, diastolic function was significantly ameliorated as several diastolic parameters were improved by the treatment in diabetic models [45]. Notably, pretreatment of mice with pioglitazone improved both systolic and diastolic functions regardless of the etiologic cause, being either ischemia $[44,46]$, pressure overload or high-fat diet [43]. It also reduced aortic valve calcification in non-diabetic, hypercholesterolemic rats [47].

\section{Cardiac remodeling \\ Human studies}

Few studies reported the effects of pioglitazone on changes in cardiac size and function, the results being somewhat controversial. Mean aortic diameter and left atrial systolic and diastolic volumes significantly decreased after 6 months of therapy with pioglitazone in 49 T2D subjects [38]. However, different authors reported that pioglitazone treatment was associated with a $17 \%$ increase in left atrial volume in 30 T2D patients after 26 weeks of pioglitazone treatment [33], while others [36] found no change in absolute values of left atrium volume and LV end-diastolic diameter in 30 non-diabetic patients with essential hypertension after 6 month pioglitazone treatment. The different response may be due to the rather small sample size of these observation, coupled with the different baseline characteristics of the patients. As such, there is still uncertainty about pioglitazone effect on cardiac remodeling in humans, and mechanisms are still unknown. Noteworthy, pioglitazone reduces plasma collagen III in humans [37], possibly exerting anti-fibrotic effects.

\section{Animal studies.}

In vitro and in vivo observations showed pioglitazone to have anti-hypertrophic potential in cultured mice cardiomyocytes via inhibition of vascular endothelial growth factor (VEGF) [48] and inhibition of pressure overloadinduced increases in cardiac wall thickness and myocyte diameter in wild-type mice. Moreover, it reduced the increase in the heart weight-to-body weight ratio in heterozygous non-diabetic PPAR- $\gamma$-deficient mice [49], suggesting PPAR- $\gamma$ independent activity. Moreover, it was shown to have beneficial long-term effects on cardiac remodeling in non-diabetic stroke-prone rodents by normalizing echo-assessed left ventricle (LV) geometry, reversing concentric remodeling, and decreasing myocyte diameter, interstitial fibrosis and number of myofibroblasts [50]. These effects are coupled with the inactivation of well-established transcription factors involved in cardiomyocyte hypertrophy NFATc2 and $\mathrm{NF}-\mathrm{kB} / \mathrm{p} 65$ [51] that coordinate a program of reactivation of fetal ventricular gene expression profiles typical of (adverse) cardiac remodeling [52]. In this scenario, convincing data support the anti-fibrotic effect of pioglitazone in cardiac remodeling in several studies documenting a consistent reduction of histologically proven cardiac fibrosis after pioglitazone treatment [53, 54]. Particularly, in a model of non-diabetic ischemia-reperfusion injury, pioglitazone reduced the synthesis of extracellular matrix, particularly collagen I and III, tissue inhibitor of metalloproteinase (TIMP)-1, and matrix metalloproteinase (MMP)-2 in cardiac fibroblasts, a pathway involving the PPAR- $\gamma$-dependent inhibition of NF- $k$ B [55]. Also, inhibition of connective tissue growth factor (CTGF) expression [50] and attenuated angiotensin II-induced cardiac fibrosis by reduced myocardial macrophage infiltration were reported [56]. Other recent works observed reduced fibrosis through reduced expression of TGF- $\beta$ in macrophages from diabetic mice [57] through PTEN [58], Smad3 activation [59], and the newly discovered SIRT3/ $\beta$-catenin/PPAR- $\gamma$ axis, which prevent cardiac fibroblasts from transdifferentiating into myoblasts [60]. Based upon these observations, PPAR- $\gamma$ agonists have been tested as potential therapeutic agents in the suppression of collagen synthesis in the lung and the liver, both in vitro and in vivo [61], with encouraging results.

\section{Electrophysiology and arrhythmias Human studies}

Several trials demonstrated that pioglitazone treatment might have beneficial influence in atrial fibrillation (AFib). Although it did not influence the recurrence of persistent AFib after successful electrical cardioversion in T2D subjects [62], it proved effective in reducing the rate of progression from persistent to permanent AFib [63], improved the preservation of sinus rhythm and reduced the reablation rate in diabetic patients with paroxysmal AFib after catheter ablation [64]. These results were confirmed by one metanalysis conducted in 2017 on more than 1,30,000 diabetic patients in which pioglitazone treatment was associated with a $30 \%$ risk reduction of developing AFib $(\mathrm{OR}=0.73, \mathrm{p}=0.0003)$ with reduced risk for both new-onset AFib $(O R=0.77, p=0.002)$ and AFib recurrence $(O R=0.41, p=0.002)$ [65]. As a consequence, pioglitazone has been proposed for AFib primary and secondary prevention in diabetes [66]. The mechanism might rely either on its anti-fibrotic effects 
(as discussed above) or on the reduction of glycation end products [63], although this is not clear.

\section{Animal studies}

Pioglitazone prevented AFib by increased membrane potential through electrophysiological remodeling both reduced angiotensin 2-induced potassium channel remodeling on isolated non-diabetic animal atrial myocytes and attenuation of angiotensin 2-induced L-type calcium channel remodeling [67]. Furthermore, it can reduce atrial fibrosis and normalize interatrial conduction time [68] by suppression of angiotensin 2-induced CTGF expression and proliferation in atrial fibroblasts from both diabetic and non-diabetic animals, with mechanisms encompassing various signaling pathways such as TGF- $\beta 1 / \mathrm{Smad} 2 / 3$ and TGF- $\beta 1 /$ TRAF6/TAK1 $[69,70]$, p-ERK1/2, p-JNK, the mitochondrial apoptotic signaling pathway, and the caspase system [67]. The mechanism is independent from the metabolic effects of the drug, and seemingly acts through the PPAR- $\gamma$ receptor [67], but this was never directly demonstrated. In canine ventricular myocytes [71], high doses of pioglitazone altered a wide variety of ion currents in a concentration-dependent manner, namely $\mathrm{I}_{\mathrm{Na}}, \mathrm{I}_{\mathrm{to}}, \mathrm{I}_{\mathrm{Ca}}, \mathrm{I}_{\mathrm{Kr}}, \mathrm{I}_{\mathrm{Ks}}, \mathrm{I}_{\mathrm{K} 1}$, and the ATPsensitive potassium current. However, it is not likely that normally dosed pioglitazone can significantly alter ventricular electrogenesis in healthy humans, apart from overdose or inherited or acquired long QT syndrome, wherein it might favor arrhythmias and particularly early afterdepolarizations. However, no sudden cardiac death has ever been reported with pioglitazone therapy.

\section{Energetic metabolism Human studies}

In cardiomyocytes, just like in adipose tissue, the genes activated by PPAR- $\gamma$ stimulate lipid uptake and adipogenesis [72]. As such, alterations in its cardiac expression cause disturbances in glucose and fatty acids metabolism, contributing to intracellular triglyceride accumulation and cardiac lipotoxicity [73] with resulting significant LV dysfunction [74]. In humans, pioglitazone treatment enhances insulin-stimulated myocardial glucose uptake as measured through ${ }^{18}$ FDG PET across the whole spectrum of glucose tolerance $[32,41,75]$, including T2D with coronary artery disease [76]. This is related to a reduction of serum free fatty acids [77, 78], since pioglitazone promotes fatty acid transport into the cardiomyocytes inducing the expression of fatty acid-binding protein 4 (FABP4) and fatty acid translocase (FAT)/CD36 in capillary endothelial cells [79]. However, the clinical implications are poorly known, and more studies are required. Interestingly, since right ventricular dysplasia has been linked to changes in PPAR- $\gamma$-dependent pathways in cardiomyocytes energetic metabolism leading to myosin dysfunction [80], pioglitazone has been proposed as a possible therapy for this condition, by acting through alterations in PPAR- $\gamma$-dependent $\mathrm{Wnt} / \beta$-catenin canonical pathway [81].

\section{Animal studies}

Due to low myocardial PPAR- $\gamma$ expression, in vivo effects of TDZs on cardiac metabolism are generally thought to be indirect and secondary to their lipid lowering properties [82], and a direct regulation of cardiac metabolism by PPAR $\gamma$ remains a subject of debate. Pioglitazone can induce lipid accumulation in the heart of rats despite concurrent reduction in plasma free fatty acids concentration, thus suggesting a direct action of PPAR $\gamma$ agonist on the cardiomyocyte [83] and seemingly a de novo synthesis of ceramides [84]. More recently it has shown that tissue-specific loss of PPAR $\gamma$ alters heart function and induces myocardial hypertrophy $[85,86]$ with mitochondrial oxidative damage [86] although no effect on gene expression controlling lipid and glucose metabolism at baseline was observed [85]. This modulation of cardiomyocyte metabolism might have a direct effect on the functions of the heart. Indeed, PPAR- $\gamma$ transgenic mice over-expressing PPAR- $\gamma$ develop a dilated cardiomyopathy with evidence of increased lipid and glycogen stores, increased mRNA levels of genes for fatty acids oxidation, and distorted architecture of the mitochondrial inner matrix [87]. In contrast, treatment with PPAR- $\gamma$ agonists improved heart function in rodent models of lipotoxic dilated cardiomyopathy with unclear mechanisms [88, 89], since rosiglitazone treatment of wild-type mice reduced expression of PPARY targets [87].

\section{Ischemia-reperfusion injury Human studies}

Several observations reported a protective effect on myocardial ischemia-reperfusion injury. In diabetic patients with ST-elevation MI (STEMI), pretreatment with pioglitazone resulted in better myocardial reperfusion. This was described by blush score, slow flow/no-reflow phenomenon, resolution of ST elevation, and lesser reperfusion injury as defined by absence of reperfusion arrhythmias, better improvement of LVEF, and lower peak creatin kinase levels [90].

\section{Animal studies}

In animals, available evidence showed reduction in infarct size in mice and rats acutely pretreated with pioglitazone [91-95] through enhanced anti-oxidant superoxide dismutase and glutathione peroxidase concentrations [93], activation of ERK and COX2 [96], and reduced cardiomyocyte apoptosis via enhanced $\mathrm{Bcl}-2$ 
protein expression, reduced Bax and caspase 3 protein expression [46]. Also, pioglitazone attenuated reperfusion arrhythmias after ischemic-reperfusion injury in diabetic rats [97], and ameliorated the deteriorated ischemic preconditioning found in diabetic animals [98, 99]. The treatment with PPAR- $\gamma$ agonists decreased the expression of pro-inflammatory markers and reduced accumulation of neutrophils and macrophages in animal reperfused myocardium possibly through activation of NF-kB [100], an observation confirmed by a recent study in PPAR- $\gamma$ knock-out mice [55]. As such, supported by the observation that an anti-inflammatory effect is coupled with protection from ischemia in other tissues alike -namely liver [101], kidney [102], and gut [103]-, we can hypothesize that pioglitazone might in part protect from ischemia-reperfusion injury via an anti-inflammatory effect. Still, the drug might also exert its protective effect on ischemia via a metabolic action mediated by cardiomyocyte-derived adiponectin [104], which has been observed to be protective during ischemia [105].

\section{Neurohormonal activation Human studies}

Pioglitazone can modulate diverse neurohormonal systems that are known to positively affect the cardiovascular system. In obese subjects with metabolic syndrome, the sympathetic nervous system response to an oral carbohydrate load is enhanced by pioglitazone, with significant increase in overall norepinephrine spillover response [106], despite no changes in resting sympathetic drive or norepinephrine disposition [39]. It can also increase adiponectin release [104] with beneficial effects on diastolic function in hypertensive patients [36]; notably, this is one of the mechanisms proposed for the beneficial effects of SGLT-2 inhibitors. One trial on 94 diabetic patients undergoing coronary angioplasty reported a significant reduction of brain natriuretic peptide (BNP) levels with pioglitazone with respect to other hypoglycemic treatments [17]. Similarly, lower BNP values [107] in 223 diabetic subjects reported with the combined sulphonylurea-pioglitazone therapy with respect to other medications. On the contrary, two smaller studies observed a significant increase in BNP values during pioglitazone treatment $[108,109]$, with elevated BNP values at baseline predicting a subsequent increase [109], suggesting that pioglitazone negative effect on BNP may only occur when cardiac function is already altered. One study on 30 diabetic subjects revealed an increase in $\mathrm{N}$-terminalproBNP (NT-proBNP) after 6 months of treatment with pioglitazone with a parallel slight increase in LV and left atrial volumes [33], leaving the question open.

\section{Animal studies}

At the cellular level, it can down-regulate the expression of angiotensin receptor type 1 (AT1-R) in neonatal non-diabetic rat cardiac fibroblasts, thus reducing the angiotensin-induced cardiac fibrosis and remodeling [110]. This might explain the slight increase of renin activity observed with pioglitazone in healthy subjects [111]. Also, PPAR- $\gamma$ activators directly inhibited strainand reperfusion-induced BNP expression in non-diabetic cultured cardiomyocytes and cardiac fibroblasts $[55,112]$.

\section{Pulmonary vasculature and right ventricular function Human studies}

In human pulmonary vascular wall, PPAR- $\gamma$ receptors are normally expressed by endothelial and smooth muscle cells [113], while their expression appears diminished in patients with primary and secondary pulmonary hypertension [114]. In isolated pulmonary arteries from healthy subjects, pioglitazone induced a concentration- and time-dependent relaxation with a mechanism involving nitric oxide $(\mathrm{NO})$ production that is only partially dependent on vascular endothelium and dependent on PPAR- $\gamma$ activity [115].

\section{Animal studies}

Similarly to humans, several animal studies reported improved pulmonary hypertension and right ventricle (RV) hypertrophy [116], pulmonary hypertension prevention $[117,118]$ and pulmonary vasculature remodeling [119] by PPAR- $\gamma$-dependent inhibition of transcription factors NFAT and NF- $k$ B [120]. The drug might also have a role in reducing right ventricular dysfunction $[121,122]$, via inhibition of NF- $k$ B and NFAT in cardiomyocytes of the failing RV [121] and normalize epigenetic and transcriptional regulation factors [123] primarily related to insulin resistance, disturbed lipid metabolism and mitochondrial morphology/function $[121,124,125]$.

\section{Effects of pioglitazone on the vascular system}

Several human and animal studies suggest a beneficial role for pioglitazone on the vascular system, particularly on atherosclerosis reduction. The effects of pioglitazone on the vascular system are schematized in Fig. 3.

\section{Human studies}

Pioglitazone can reduce aortic pulse wave velocity (PWV) irrespective of the presence of diabetes [126], and slow progression of carotid intima-media thickness in T2D subjects as measured with either 


\section{Pioglitazone}

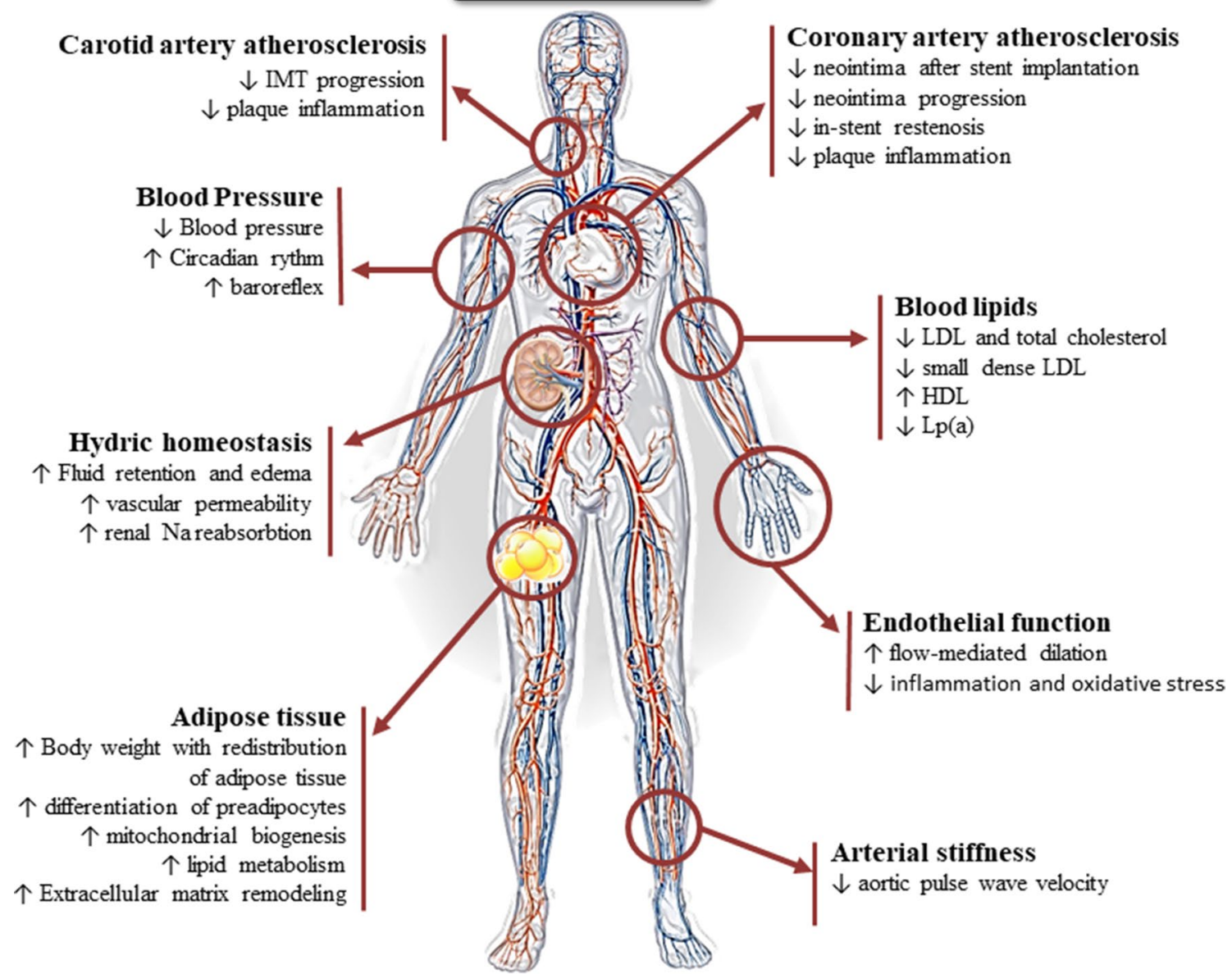

Fig. 3 Effects of pioglitazone on the vascular system and on cardiovascular risk factors. The effects of the treatment with pioglitazone on the vasculature and on modifiable risk factors are illustrated. The effects on atherosclerosis, endothelial function and blood pressure are reported, together with hydro-electrolyte homeostasis, the effects on the adipose tissue, and on blood lipids. For more details, see main text

ultrasonography [127-129] or fluorodeoxyglucose positron emission tomography/computed tomography (FDG-PET/CT) [130]. This was also observed both in non-diabetic patients with stable coronary artery disease and carotid plaques [130] and in glucose-intolerant patients [131]. Furthermore, pioglitazone positively affects plaque remodeling by inducing reduced coronary neointima hyperplasia in diabetic subjects [132], diminished intravascular ultrasonography (IVUS)assessed neointima volume after stent implantation in non-diabetic subjects [133, 134], and slowed progression of coronary atherosclerosis as quantified through IVUS in comparison to glimepiride in 360 diabetic subjects with coronary atherosclerosis [135]. Noteworthy, it significantly decreased in-stent restenosis after coronary stent implantation in T2D patients [136] as also confirmed by a later metanalysis [137]. On the contrary, no beneficial effect was seen by Lee et al. [138] neither on in-stent restenosis nor on coronary plaque volume measured by IVUS, though this might be due to the low administered dose $(15 \mathrm{mg} / \mathrm{die})$. Two metanalysis studied the effect of pioglitazone in reducing the instent restenosis and coronary atherosclerosis. The first by Zhang MD et al. [139] in 2014 reported a neutral effect, while the second by Zhao SJ et al. [140] in 2016 reported a beneficial effect for pioglitazone both on in-stent restenosis $(0.48,0.35-0.68)$ and target lesion revascularization $(0.58,0.38-0.87)$. Furthermore, several studies investigated the effect of pioglitazone on endothelial function in humans through flow-mediated dilation in brachial artery in either diabetic [141, 142], glucose intolerant [143, 144], or non-diabetic [126] patients demonstrating a significant beneficial effect for pioglitazone on ameliorating endothelial 
dysfunction irrespective of glucose tolerance phenotype, a result further confirmed by a recent metanalysis [145]. Intriguingly, this appears to be independent of its insulin-sensitizing action [146, 147], and possibly related to the known increase in adiponectin levels [143]. Nonetheless, in the study by Davidson et al. [148] the reduction of carotid intima-media progression was related to an increase in HDL cholesterol at 24 weeks of treatment, suggesting that even other factors might be at play.

The mechanisms seemingly rely on anti-inflammatory and anti-oxidative effects, reducing carotid plaque inflammation in patients with higher baseline inflammation [130], reducing circulating natural killer cells, diminishing IL-6 and monocyte chemoattractant protein (MCP)-1 -also known as GDF15- levels, downregulating chemokine receptor 2 at $48 \mathrm{~h}$ after stent implantation in T2D [134]. With pioglitazone treatment, lower IL-10 levels at ten days after implantation was achieved, together with possible anti-proliferative effects on vascular smooth muscle cells [134]. This hypothesis is supported by the correlation of reduced aortic PWV with the reduction of clinical and biohumoral indices of inflammation in non-diabetic subjects with rheumatoid arthritis [126].

\section{Animal studies}

In animals, PPAR- $\gamma$ activation has been implied in inhibiting VEGF-induced angiogenesis [149] and in decreasing the inflammatory response of several cardiovascular structures, particularly endothelial cells [150]. Pioglitazone can also protect endothelial progenitor cells from hyperhomocysteinemia via reduced reactive oxygen species (ROS) production by NADPH and PKC downregulation [151], inhibition of TGF $\beta 1$-induced mitochondrial activation and vascular smooth muscle cell proliferation by regulating two glucose metabolism-related enzymes, platelet isoform of phosphofructokinase (PFKP, a PPAR- $\gamma$ target, via miR-331-5p) and protein phosphatase 1 regulatory subunit 3G (PPP1R3G, a Smad3 target) [152]. Further, pioglitazone treatment suppressed excess lipid accumulation and superoxide production in the aorta in an angiotensin II-induced rat model of hypertension and retarded the progression of atherosclerosis [153]. Moreover, PPAR- $\gamma$ agonists have been shown to downregulate both basal and TNF- $\alpha$-induced Receptor for the advanced glycation end products (RAGE) expression in endothelial and mesangial cells [154], and to reduce the production of endothelin-1 and ROS by directly blocking cyclo-oxygenase (COX)-2 [155], exerting a protective effect on endothelial dysfunction through anti-oxidant activity. Notably, in spontaneously hypertensive rats, pioglitazone improved $\mathrm{NO}$ availability through increased
NO synthetase (NOS) expression and AT2R with an overall significant blood pressure reduction effect [156].

\section{Effects of pioglitazone on cardiovascular risk factors}

Body weight, adipose tissue, and blood lipid profile

Pioglitazone treatment is associated with an increase in insulin sensitivity in diabetic subjects, notwithstanding its neutral [157] or increasing effect in body weight of about $2.5-3 \mathrm{~kg}$ [158]. This is due to a change in adipose tissue distribution with reduced visceral fat in favour of subcutaneous fat $[157,159-161]$; in non-diabetic individuals it promotes an increase in total body fat content with preferential accumulation in the lower body parts and reduction in waist-to-hip ratio [162]. Both in animals [163] and humans [161, 162, 164], pioglitazone increases the number and the activity of small adipocytes promoting differentiation of preadipocytes to adipocytes in visceral and subcutaneous adipose tissue stimulating glucose uptake, storage, and metabolism $[165,166]$. In adipose tissue, pioglitazone induces mitochondrial biogenesis, the synthesis of mitochondrial lipid metabolism enzymes [167, 168], and alters extracellular matrix and cytoskeletal proteins [167]. A deeper characterization of the metabolic effects of pioglitazone in human adipose tissue is needed, since some cardioprotective mechanisms might involve adipocytokines. Furthermore, pioglitazone treatment determines a reduction in total cholesterol, LDL-cholesterol, triglycerides, and plasma free fatty acids; it also converts small dense atherogenic LDL particles into larger ones, and increases HDL-cholesterol [169-171]. Remarkably, pioglitazone treatment reduces Lp (a) [169] as well as procoagulant factors [172]. According to the current knowledge, all these mechanisms are expected to provide cardiovascular benefits.

\section{Blood pressure \\ Human studies}

A slight but consistent blood pressure lowering effect has been consistently reported with pioglitazone [39, 40, $128,141,173-175]$, achieving an average reduction by $3-5 \mathrm{mmHg}$ in systolic blood pressure after 12 months of treatment. Interestingly, pioglitazone at the oral dose of $30 \mathrm{mg} /$ die was effective in normalizing both blood pressure and serum potassium levels in one case of resistant hypertension due to primary hyperaldosteronism in a diabetic subject [176]. In fact, a slight antagonistic effect on the angiotensin receptors has been observed, with a consequent increase in plasma renin activity [111]. Aside from its direct effect on absolute blood pressure values, its protective effect is seemingly dependent upon a reassessment of the cardiovascular circadian clock, being PPAR- $\gamma$ a main component of the vascular system 
circadian regulation, known to be altered by metabolic pathologic conditions such as obesity and diabetes [177, 178]. In diabetic patients, pioglitazone is known to reestablish the circadian rhythm of blood pressure from a "non-dipper" to a "dipper" pattern, restoring the nocturnal decline in blood pressure in parallel with reduction in the HOMA index $[179,180]$. Decreased blood pressure and enhanced baroreflex sensitivity with pioglitazone was reported after an oral carbohydrate load in obese subjects with metabolic syndrome [106], and there is initial evidence that this drug might have a beneficial role in restoring the sympatho-vagal balance in diabetic autonomic cardiomyopathy [181].

\section{Animal studies}

The observations on humans are confirmed in animal studies [182] in hypertensive models [156, 183] wherein a reduction in hypertension-related end organ damage, including (LV) hypertrophy [184], proteinuria [185], and white matter lesions and cognitive impairment were reported [186]. One plausible determinant of the antihypertensive effect of piogliazone is the attenuation of vascular contractility via a NO-independent mechanism that directly involves intracellular calcium handling through the inhibition of L-type $\mathrm{Ca}^{2+}$ currents in vascular smooth muscle cells [187] independently and synergistically with insulin [188]. Pioglitazone can directly regulate Rev-erb- $\alpha$, a transcription factor influencing Brain and Muscle Arnt-Like protein (BMAL)-1 [178, 189], a key clock-gene involved in cardiovascular rhythmicity [190] and possibly accounting for its effect on the circadian clock. Yet, whether the main target cells of pioglitazone are vascular smooth muscle cells, liver, peripheral adipose tissue, or perivascular adipose tissue is still matter of debate [178].

\section{Fluid and electrolyte homeostasis}

Oedema was early recognized as a frequent and potentially clinically relevant side effect of pioglitazone, possibly precipitating HF.

\section{Human studies}

Fluid retention and peripheral oedema were reported in $4-7 \%$ of pioglitazone-treated patients, that is $3-4$ times more frequent than placebo, an effect even greater in combination with other oral anti-hyperglycemic treatments (up to 15-18\%) -and especially insulin therapy ( 22\%) [191, 192]. The mechanism, which can be not always counteracted by diuretic therapy and that is relieved by drug withdrawal, is seemingly multifactorial and still poorly understood. In fact, pioglitazone can inhibit L-type calcium currents [187] thus possibly having an effect similar to that of dihydropyridine calcium channel blockers. It also increases VEGF activity [193] which leads to capillary wall permeabilization. Yet, renal sodium-water increased reabsorption plays a major role, accounting for up to $80-90 \%$ of thiazolidinedionesrelated fluid retention [194]. In human proximal tubule cells this is mainly achieved through enhanced expression of sodium-hydrogen exchangers (NHE3) [195-198], proximal tubule aquaporine (AQP) 1 and 7 channels [196], and possibly a direct pioglitazone-driven sodium reabsorption [111]. Moreover, insulin has been known to stimulate sodium absorption along various nephron segments, potentially acting synergistically with pioglitazone [199] and possibly accounting for the greater incidence of oedema formation during combined therapy.

\section{Animal studies}

Animal studies report conflicting results on a reduction in glomerular filtration rate with an effect size that was largely overcome by tubular reabsorption [200, 201]. This result was later confirmed by the potent PPAR $\gamma$ agonist, farglitazar (GI262570), which induced plasma volume expansion in normal rats with significant reduction of hematocrit, hemoglobin, and serum albumin concentration but no measurable effect on GFR, renal blood flow, or filtration fraction [202]. These results suggest that thiazolidinediones-induced fluid retention occurs mainly by tubular rather than glomerular mechanism. Several works suggest that it might induce plasma volume expansion acting either on the cortical collecting duct via enhanced expression of the $\gamma$ subunit of epithelial $\mathrm{Na}$ channel $(\mathrm{ENaC})$ [203], or on the renal proximal tubule through sodium-coupled bicarbonate transporters, sodium-hydrogen exchangers, NHE3 [200], and basolateral rheogenic $\mathrm{Na}^{+} / \mathrm{HCO} 3$ cotransport (NBCe1) [204]. Finally, also the Henle's loop bumetanide-sensitive $\mathrm{Na}-\mathrm{K}-2 \mathrm{Cl}$ cotransporter (NKCC) may be upregulated by pioglitazone [205]. However, the exact mechanisms accounting for the renal effects of pioglitazone remain unclear.

\section{Clinical considerations}

Pioglitazone has some adverse effects that warrant caution in at risk patients and limited its use in clinical practice, including body weight gain, peripheral oedema, increased congestive HF risk, decreased bone mineral density, dilution anemia, and possibly increased risk for bladder cancer [2]. Despite these safety concerns, pioglitazone has recently gained renewed popularity after several clinical trials reporting reduction in atherosclerosis, AFib, and atherosclerosis-related events. Of note, it positively modulates numerous cardiovascular functions and risk factors such as systemic blood pressure, blood lipids, and adipose tissue physiology, thus leading to slowed 
atherosclerosis progression. It can also restore cardiovascular rhythmicity, increase LV systo-diastolic functions, protect against myocardial ischemia and fibrosis, as well as possibly reduce pulmonary hypertension. The exact mechanisms remain unclear, seemingly encompassing anti-inflammatory, anti-oxidative, anti-hypertrophic, anti-fibrotic, and vasodilatory effects -both PPAR- $\gamma$ dependent and independent, which to date remain rather unclear in their precise molecular mechanisms. In this scenario, it is important to underscore that the treatment with pioglitazone is low-cost, widely available, without significant drug interactions, and with little side effects such as mild body weight gain and risk of oedema formation. Even without a direct negative influence on cardiac function, the retentive effect of pioglitazone may be clinically relevant, as it can possibly lead to overt HF by unmasking previously undiagnosed cardiac dysfunction. However, with aware appropriate prescription and titration in those with or at high risk for acute decompensated $\mathrm{HF}$, the above described polyhedric cardiovascular benefits of pioglitazone identify this drug as a useful tool in the arsenal of the clinical diabetologist, particularly when used in combination with SGLT-2 inhibitors. In fact, the depletion of extracellular fluid volume by SGLT-2 inhibitors is expected to contrast the expansion of fluid volume by TZDs, while the beneficial effects on cardiovascular prevention of the two drug classes are potentially additive or even multiplicative, due to their different mechanisms of action. For these arguments, TZDs and SGLT-2 inhibitora have been proposed by DeFronzo et al. [206, 207] as ideal partners in combination therapy. Therefore, a diabetic subject with insulin resistance, non-controlled or non-dipper hypertension, and at high risk for or with multi-vessel atherosclerosis perfectly fits the ideal candidate for pioglitazone. The concomitants reduction of paroxysmal AFib incidence of recurrence further support the therapeutic choice.

\section{Concluding remarks}

Pioglitazone is a PPAR- $\gamma$ agonist acting as an insulin sensitizer with cardiovascular protective potential, despite the risk of fluid imbalance in overt HF. The pleiotropic and beneficial effects on cardiovascular risk factors are exerted above and beyond glycemic improvement, encompassing myocardial beneficial effects both directly, through anti-fibrotic and antiremodeling actions, and indirectly, by improving vascular homeostasis. Accordingly, clinical trials have observed its capacity of slowing atherosclerosis progression, possibly accounting for the reduction in cardio- and cerebrovascular events. The mechanisms involved might rely either on cardiac and vascular anti-remodeling properties (endothelium protective, inflammation-modulating, anti-proliferative and antifibrotic properties) and/or on metabolic (adipose tissue metabolism, increased HDL cholesterol) and neurohormonal (renin-angiotensin-aldosterone system, sympathetic nervous system, and adiponectin) modulation of the cardiovascular system. These polyhedric beneficial effects make pioglitazone a useful tool in the arsenal of the clinical diabetologist, especially in the insulinresistant, hypertensive patient at high cardiovascular risk.

\section{Abbreviations \\ AFib: Atrial fibrillation; AT-R1: Angiotensin receptor type 1; BNP: Brain natriuretic peptide; COX: Cyclo-oxygenase; CVD: Cardiovascular disease; E/A ratio: Early-to-atrial mitral inflow Doppler wave ratio; ENaC: Epithelial sodium channel; GLP-1: Glucagone like peptide 1; HDL: High density lipoproteins; HF: Heart failure; IVUS: Intravascular ultrasonography; LDL: Low density lipo- proteins; Lp (a): Lipoprotein a; LV: Left ventricle; LVEF: Left ventricular ejection fraction; MACE: Major adverse cardiovascular events; NF-kB: Nuclear factor k-B; NO: Nitric oxide; NOS: Nitric oxide synthetase; NT-proBNP: N terminal-pro brain natriuretic peptide; PPAR-y: Peroxisome proliferator-activated receptor gamma; PWV: Pulse wave velocity; RAGE: Receptor for the advanced glycation end products; RCTs: Randomized clinical trials; ROS: Reactive oxygen species; RV: Right ventricle; SGLT-2: Sodium-glucose cotransporter 2; STEMI: ST eleva- tion myocardial infarction; T2D: Type 2 diabetes; TDZs: Thiazolidinediones; VEGF: Vascular endothelial growth factor.}

\section{Acknowledgements}

The authors are grateful to the personnel of the Metabolism, Nutrition, and Atherosclerosis Laboratory for the support and the collaboration.

\section{Authors' contributions}

LN conceived and designed the paper, performed the literature review, wrote the manuscript, and ideated and produced the figures. DT performed the literature review, wrote the manuscript, ideated and produced the figures, and critically revised the manuscript. AM performed the literature review, wrote the manuscript, and critically revised the manuscript. AN provided a substantial contribution to the analysis and interpretation of the data and critically revised the manuscript. All authors read and approved the final manuscript.

Funding

No funding was required for writing this paper.

Availability of data and materials

Not applicable.

\section{Declarations}

Ethics approval and consent to participate

Not applicable.

Consent for publication

All the Authors gave their consent to publication.

Competing interests

The authors have no conflict of interest to declare.

\section{Author details}

'Metabolism, Nutrition, and Atherosclerosis Laboratory, Department of Clinical and Experimental Medicine, University of Pisa, Via Savi 10, 56126 Pisa, Italy.

${ }^{2}$ Cardiopulmonary Laboratory, Department of Clinical and Experimental Medicine, University of Pisa, Pisa, Italy. ${ }^{3}$ Department of Surgical, Medical and Molecular Pathology and Critical Care Medicine, Pisa, Italy. ${ }^{4}$ Institute of Life Sciences, Sant'Anna School of Advanced Studies, Pisa, Italy. 
Received: 27 February 2021 Accepted: 29 April 2021

Published online: 18 May 2021

\section{References}

1. Gale EA. Lessons from the glitazones: a story of drug development. Lancet. 2001;357(9271):1870-5.

2. Alam F, Islam MA, Mohamed M, Ahmad I, Kamal MA, Donnelly R, Idris I, Gan SH. Efficacy and safety of pioglitazone monotherapy in type 2 diabetes mellitus: a systematic review and meta-analysis of randomised controlled trials. Sci Rep. 2019;9(1):5389.

3. Davidson MB. The glycemic, cardiovascular and hepatic outcomes of pioglitazone treatment: evidence for its increased use. J Gastroenterol Sci. 2020;1(1):5

4. Lebovitz HE. Thiazolidinediones: the forgotten diabetes medications. Curr Diab Rep. 2019. https://doi.org/10.1007/s11892-019-1270-y.

5. Kernan WN, Viscoli CM, Furie KL, Young LH, Inzucchi SE, Gorman M, Guarino PD, Lovejoy AM, Peduzzi PN, Conwit R, et al. Pioglitazone after ischemic stroke or transient ischemic attack. N Engl J Med. 2016;374(14):1321-31

6. Vaccaro O, Masulli M, Nicolucci A, Bonora E, Del Prato S, Maggioni AP, Rivellese AA, Squatrito S, Giorda CB, Sesti G, et al. Effects on the incidence of cardiovascular events of the addition of pioglitazone versus sulfonylureas in patients with type 2 diabetes inadequately controlled with metformin (TOSCA.IT): a randomised, multicentre trial. Lancet Diabetes Endocrinol. 2017;5(11):887-97.

7. Zelniker TA, Wiviott SD, Raz I, Im K, Goodrich EL, Furtado RHM, Bonaca MP, Mosenzon O, Kato ET, Cahn A, et al. Comparison of the effects of glucagon-like peptide receptor agonists and sodium-glucose cotransporter 2 inhibitors for prevention of major adverse cardiovascular and renal outcomes in type 2 diabetes mellitus. Circulation. 2019;139(17):2022-31.

8. Nesti L, Natali A. Metformin effects on the heart and the cardiovascular system: a review of experimental and clinical data. Nutr Metab Cardiovasc Dis. 2017;27(8):657-69.

9. Ruscica M, Baldessin L, Boccia D, Racagni G, Mitro N. Non-insulin antidiabetic drugs: an update on pharmacological interactions. Pharmacol Res. 2017;115:14-24.

10. Erdmann E, Wilcox RG. Weighing up the cardiovascular benefits of thiazolidinedione therapy: the impact of increased risk of heart failure. Eur Heart J. 2008:29(1):12-20.

11. Lago RM, Singh PP, Nesto RW. Congestive heart failure and cardiovascular death in patients with prediabetes and type 2 diabetes given thiazolidinediones: a meta-analysis of randomised clinical trials. Lancet. 2007:370(9593):1129-36.

12. Young LH, Viscoli CM, Schwartz GG, Inzucchi SE, Curtis JP, Gorman MJ, Furie $\mathrm{KL}$, Conwit R, Spatz E, Lovejoy A, et al. Heart failure after ischemic stroke or tia in insulinresistant patients without diabetes treated with pioglitazone. Circulation. 2018. https://doi.org/10.1161/CIRCULATIO NAHA. 118.034763

13. Dormandy JA, Charbonnel B, Eckland DJ, Erdmann E, Massi-Benedetti M, Moules IK, Skene AM, Tan MH, Lefebvre PJ, Murray GD, et al. Secondary prevention of macrovascular events in patients with type 2 diabetes in the PROactive Study (PROspective pioglitAzone Clinical Trial In macroVascular Events): a randomised controlled trial. Lancet. 2005:366(9493):1279-89.

14. Liao HW, Saver JL, Wu YL, Chen TH, Lee M, Ovbiagele B. Pioglitazone and cardiovascular outcomes in patients with insulin resistance, prediabetes and type 2 diabetes: a systematic review and meta-analysis. BMJ Open. 2017;7(1):e013927.

15. de Jong $M$, van der Worp HB, van der Graaf $Y$, Visseren FL, Westerink J. Pioglitazone ad the secondary prevention of cardiovascular disease. A meta-analysis of randomized-controlled trials. Cardiovasc Diabetol. 2017. https://doi.org/10.1186/s12933-017-0617-4.

16. Asakura M, Kim J, Asanuma H, Nakama Y, Tsukahara K, Higashino Y, Ishikawa T, Koba S, Tsujimoto M, Himeno H, et al. Cardiovascular outcomes in patients with previous myocardial infarction and mild diabetes mellitus following treatment with pioglitazone: reports of a randomised trial from The Japan Working Group for the Assessment
Whether Pioglitazone Protects DM Patients Against Re-Infarction (PPAR study). EClinicalMedicine. 2018;4-5:10-24.

17. Tanaka A, Komukai S, Shibata Y, Yokoi H, Iwasaki Y, Kawasaki T, Horiuchi K, Nakao K, Ueno T, Nakashima H, et al. Effect of pioglitazone on cardiometabolic profiles and safety in patients with type 2 diabetes undergoing percutaneous coronary artery intervention: a prospective, multicenter, randomized trial. Heart Vessels. 2018;33(9):965-77.

18. Zhou Y, Huang Y, Ji X, Wang X, Shen L, Wang Y. Pioglitazone for the primary and secondary prevention of cardiovascular and renal outcomes in patients with or at high risk of type 2 diabetes mellitus: a metaanalysis. J Clin Endocrinol Metab. 2020. https://doi.org/10.1210/clinem/ dgz252.

19. Zinman B, Wanner C, Lachin JM, Fitchett D, Bluhmki E, Hantel S, Mattheus M, Devins T, Johansen OE, Woerle HJ, et al. Empagliflozin, cardiovascular outcomes, and mortality in type 2 diabetes. N Engl J Med. 2015:373(22):2117-28.

20. Wiviott SD, Raz I, Bonaca MP, Mosenzon O, Kato ET, Cahn A, Silverman MG, Zelniker TA, Kuder JF, Murphy SA, et al. Dapagliflozin and cardiovascular outcomes in type 2 diabetes. N Engl J Med. 2019;380(4):347-57.

21. Neal B, Perkovic V, Mahaffey KW, de Zeeuw D, Fulcher G, Erondu N, Shaw W, Law G, Desai M, Matthews DR. Canagliflozin and cardiovascular and renal events in type 2 diabetes. N Engl J Med. 2017;377(7):644-57.

22. Marso SP, Bain SC, Consoli A, Eliaschewitz FG, Jódar E, Leiter LA, Lingvay I, Rosenstock J, Seufert J, Warren ML, et al. Semaglutide and cardiovascular outcomes in patients with type 2 diabetes. N Engl J Med. 2016;375(19):1834-44.

23. Gerstein HC, Colhoun HM, Dagenais GR, Diaz R, Lakshmanan M, Pais P, Probstfield J, Riesmeyer JS, Riddle MC, Rydén L, et al. Dulaglutide and cardiovascular outcomes in type 2 diabetes (REWIND): a double-blind, randomised placebo-controlled trial. Lancet. 2019;394(10193):121-30.

24. Zhu J, Yu X, Zheng Y, Li J, Wang Y, Lin Y, He Z, Zhao W, Chen C, Qiu K, et al. Association of glucose-lowering medications with cardiovascular outcomes: an umbrella review and evidence map. Lancet Diabetes Endocrinol. 2020;8(3):192-205.

25. Mengozzi A, Tricò D, Natali A. A novel method for interpreting survival analysis data: description and test on three major clinical trials on cardiovascular prevention. Trials. 2020;21(1):578.

26. Erdmann E, Charbonnel B, Wilcox RG, Skene AM, Massi-Benedetti M Yates J, Tan M, Spanheimer R, Standl E, Dormandy JA. Pioglitazone use and heart failure in patients with type 2 diabetes and preexisting cardiovascular disease: data from the PROactive study (PROactive 08) Diabetes Care. 2007:30(11):277-8.

27. Home PD, Pocock SJ, Beck-Nielsen H, Curtis PS, Gomis R, Hanefeld M, Jones NP, Komajda M, McMurray JJ, Team RS. Rosiglitazone evaluated for cardiovascular outcomes in oral agent combination therapy for type 2 diabetes (RECORD): a multicentre, randomised, open-label trial. Lancet. 2009:373(9681):2125-35.

28. Kahn SE, Haffner SM, Heise MA, Herman WH, Holman RR, Jones NP, Kravitz BG, Lachin JM, O'Neill MC, Zinman B, et al. Glycemic durability of rosiglitazone, metformin, or glyburide monotherapy. N Engl J Med. 2006:355(23):2427-43.

29. Lu CJ, Sun Y, Muo CH, Chen RC, Chen PC, Hsu CY. Risk of stroke with thiazolidinediones: a ten-year nationwide population-based cohort study. Cerebrovasc Dis. 2013;36(2):145-51.

30. American Diabetes Association. 10.cardiovascular disease and risk management: Standards of Medical Care in Diabetes-2020. Diabetes Care. 2020:43(Suppl 1):S111-34.

31. Bozkurt B, Aguilar D, Deswal A, Dunbar SB, Francis GS, Horwich T, Jessup M, Kosiborod M, Pritchett AM, Ramasubbu K, et al. Contributory risk and management of comorbidities of hypertension, obesity, diabetes mellitus, hyperlipidemia, and metabolic syndrome in chronic heart failure: a scientific statement from the American Heart Association. Circulation. 2016;134(23):e535-78

32. Clarke GD, Solis-Herrera C, Molina-Wilkins M, Martinez S, Merovci A Cersosimo E, Chilton RJ, lozzo P, Gastaldelli A, Abdul-Ghani M, et al. Pioglitazone improves left ventricular diastolic function in subjects with diabetes. Diabetes Care. 2017;40(11):1530-6.

33. Dorkhan M, Dencker M, Stagmo M, Groop L. Effect of pioglitazone versus insulin glargine on cardiac size, function, and measures of fluid retention in patients with type 2 diabetes. Cardiovasc Diabetol. 2009:8:15. 
34. Hughes AD, Park C, March K, Coady E, Khir A, Chaturvedi N, Thom SA. A randomized placebo controlled double blind crossover study of pioglitazone on left ventricular diastolic function in type 2 diabetes. Int J Cardiol. 2013;167(4):1329-32.

35. Naka KK, Pappas K, Papathanassiou K, Papamichael ND, Kazakos N, Kanioglou C, Makriyiannis D, Katsouras CS, Liveris K, Tsatsoulis A, et al. Lack of effects of pioglitazone on cardiac function in patients with type 2 diabetes and evidence of left ventricular diastolic dysfunction: a tissue doppler imaging study. Cardiovasc Diabetol. 2010;9:57.

36. Horio T, Suzuki M, Suzuki K, Takamisawa I, Hiuge A, Kamide K, Takiuchi S, Iwashima Y, Kihara S, Funahashi T, et al. Pioglitazone improves left ventricular diastolic function in patients with essential hypertension. Am J Hypertens. 2005;18(7):949-57.

37. Terui G, Goto T, Katsuta M, Aoki I, Ito H. Effect of pioglitazone on left ventricular diastolic function and fibrosis of type III collagen in type 2 diabetic patients. J Cardiol. 2009;54(1):52-8.

38. Ordu S, Ozhan H, Alemdar R, Aydin M, Basar C, Caglar O, Yazici M, Yalcin S. Pioglitazone improves ventricular diastolic function in patients with diabetes mellitus: a tissue Doppler study. Acta Cardiol. 2010;65(4):401-6

39. Straznicky NE, Grima MT, Sari Cl, Eikelis N, Lambert GW, Nestel PJ, Karapanagiotidis S, Wong C, Richards K, Marusic P, et al. A randomized controlled trial of the effects of pioglitazone treatment on sympathetic nervous system activity and cardiovascular function in obese subjects with metabolic syndrome. J Clin Endocrinol Metab. 2014;99(9):E1701-7.

40. Pala S, Esen O, Akcakoyun M, Kahveci G, Kargin R, Tigen K, Karaahmet T, Acar G, Esen AM, Kirma C. Rosiglitazone, but not pioglitazone, improves myocardial systolic function in type 2 diabetic patients: a tissue Doppler study. Echocardiography. 2010;27(5):512-8.

41. van der Meer RW, Rijzewijk LJ, de Jong HW, Lamb HJ, Lubberink M, Romijn JA, Bax JJ, de Roos A, Kamp O, Paulus WJ, et al. Pioglitazone improves cardiac function and alters myocardial substrate metabolism without affecting cardiac triglyceride accumulation and high-energy phosphate metabolism in patients with well-controlled type 2 diabetes mellitus. Circulation. 2009:119(15):2069-77.

42. Rodriguez WE, Joshua IG, Falcone JC, Tyagi SC. Pioglitazone prevents cardiac remodeling in high-fat, high-calorie-induced type 2 diabetes mellitus. Am J Physiol Heart Circ Physiol. 2006;291 (1):H81-7.

43. Tian YQ, Li SS, Su XD, Zhang GZ, Zhao JJ, Li GW, Wang L. Effects of pioglitazone on high-fat-diet-induced ventricular remodeling and dysfunction in rats. J Cardiovasc Pharmacol Ther. 2012;17(2):223-8.

44. Shiomi T, Tsutsui H, Hayashidani S, Suematsu N, Ikeuchi M, Wen J, Ishibashi M, Kubota T, Egashira K, Takeshita A. Pioglitazone, a peroxisome proliferator-activated receptor-gamma agonist, attenuates left ventricular remodeling and failure after experimental myocardial infarction. Circulation. 2002;106(24):3126-32.

45. Kim SK, Zhao ZS, Lee YJ, Lee KE, Kang SM, Choi D, Lim SK, Chung N, Lee HC, Cha BS. Left-ventricular diastolic dysfunction may be prevented by chronic treatment with PPAR-alpha or -gamma agonists in a type 2 diabetic animal model. Diabetes Metab Res Rev. 2003;19(6):487-93.

46. Cao Z, Ye P, Long C, Chen K, Li X, Wang H. Effect of pioglitazone, a peroxisome proliferator-activated receptor gamma agonist, on ischemiareperfusion injury in rats. Pharmacology. 2007;79(3):184-92.

47. Li F, Cai Z, Chen F, Shi X, Zhang Q, Chen S, Shi J, Wang DW, Dong N. Pioglitazone attenuates progression of aortic valve calcification via down-regulating receptor for advanced glycation end products. Basic Res Cardiol. 2012;107(6):306.

48. Zhong W, Jin W, Xu S, Wu Y, Luo S, Liang M, Chen L. Pioglitazone induces cardiomyocyte apoptosis and inhibits cardiomyocyte hypertrophy via VEGFR-2 signaling pathway. Arq Bras Cardiol. 2018. https://doi. org/10.5935/abc.20180108.

49. Asakawa M, Takano H, Nagai T, Uozumi H, Hasegawa H, Kubota N, Saito T, Masuda Y, Kadowaki T, Komuro I. Peroxisome proliferator-activated receptor gamma plays a critical role in inhibition of cardiac hypertrophy in vitro and in vivo. Circulation. 2002;105(10):1240-6.

50. Shinzato T, Ohya Y, Nakamoto M, Ishida A, Takishita S. Beneficial effects of pioglitazone on left ventricular hypertrophy in genetically hypertensive rats. Hypertens Res. 2007;30(9):863-73.

51. Liu Q, Chen Y, Auger-Messier M, Molkentin JD. Interaction between NFkappaB and NFAT coordinates cardiac hypertrophy and pathological remodeling. Circ Res. 2012;110(8):1077-86.
52. Swynghedauw B. Phenotypic plasticity of adult myocardium: molecular mechanisms. J Exp Biol. 2006;209(Pt 12):2320-7.

53. Wei WY, Zhang N, Li LL, Ma ZG, Xu M, Yuan YP, Deng W, Tang QZ. Pioglitazone alleviates cardiac fibrosis and inhibits endothelial to mesenchymal transition induced by pressure overload. Cell Physiol Biochem. 2018;45(1):26-36.

54. Qi HP, Wang Y, Zhang QH, Guo J, Li L, Cao YG, Li SZ, Li XL, Shi MM, Xu W, et al. Activation of peroxisome proliferator-activated receptor gamma (PPARgamma) through NF-kappaB/Brg1 and TGF-beta1 pathways attenuates cardiac remodeling in pressure-overloaded rat hearts. Cell Physiol Biochem. 2015;35(3):899-912.

55. Makino N, Sugano M, Satoh S, Oyama J, Maeda T. Peroxisome proliferator-activated receptor- $\gamma$ ligands attenuate brain natriuretic peptide production and affect remodeling in cardiac fibroblasts in reoxygenation after hypoxia. Cell Biochem Biophys. 2006;44(1):065-72.

56. Caglayan E, Stauber B, Collins AR, Lyon CJ, Yin F, Liu J, Rosenkranz S, Erdmann E, Peterson LE, Ross RS, et al. Differential roles of cardiomyocyte and macrophage peroxisome proliferator-activated receptor gamma in cardiac fibrosis. Diabetes. 2008;57(9):2470-9.

57. Hamza AA, Fikry EM, Abdallah W, Amin A. Mechanistic insights into the augmented effect of bone marrow mesenchymal stem cells and thiazolidinediones in streptozotocin-nicotinamide induced diabetic rats. Sci Rep. 2018;8(1):9827.

58. Lee KS, Park SJ, Hwang PH, Yi HK, Song CH, Chai OH, Kim JS, Lee MK, Lee YC. PPAR-gamma modulates allergic inflammation through up-regulation of PTEN. FASEB J. 2005;19(8):1033-5.

59. Fu M, Zhang J, Zhu X, Myles DE, Willson TM, Liu X, Chen YE. Peroxisome proliferator-activated receptor gamma inhibits transforming growth factor beta-induced connective tissue growth factor expression in human aortic smooth muscle cells by interfering with Smad3. J Biol Chem. 2001:276(49):45888-94.

60. Guo X, Yan F, Shan X, Li J, Yang Y, Zhang J, Yan X, Bu P. SIRT3 inhibits Ang II-induced transdifferentiation of cardiac fibroblasts through betacatenin/PPAR-gamma signaling. Life Sci. 2017;186:111-7.

61. Galli A, Crabb DW, Ceni E, Salzano R, Mello T, Svegliati-Baroni G, Ridolfi F, Trozzi L, Surrenti C, Casini A. Antidiabetic thiazolidinediones inhibit collagen synthesis and hepatic stellate cell activation in vivo and in vitro. Gastroenterology. 2002;122(7):1924-40.

62. Gu J, Hu W, Song ZP, Liu X, Zhang DD. PPARgamma agonist use and recurrence of atrial fibrillation after successful electrical cardioversion. Hellenic J Cardiol. 2017;58(5):387-90.

63. Liu B, Wang J, Wang G. Beneficial effects of pioglitazone on retardation of persistent atrial fibrillation progression in diabetes mellitus patients. Int Heart J. 2014;55(6):499-505.

64. Gu J, Liu X, Wang X, Shi H, Tan H, Zhou L, Gu J, Jiang W, Wang Y. Beneficial effect of pioglitazone on the outcome of catheter ablation in patients with paroxysmal atrial fibrillation and type 2 diabetes mellitus. Europace. 2011;13(9):1256-61.

65. Zhang Z, Zhang X, Korantzopoulos P, Letsas KP, Tse G, Gong M, Meng L, Li G, Liu T. Thiazolidinedione use and atrial fibrillation in diabetic patients: a meta-analysis. BMC Cardiovasc Disord. 2017;17(1):96.

66. Liu C, Liu T, Li G. Pioglitazone may offer therapeutic advantages in diabetes-related atrial fibrillation. Int J Cardiol. 2013;168(2):1603-5.

67. Liu C, Liu R, Fu H, Li J, Wang X, Cheng L, Korantzopoulos P, Tse G, Li G, Liu T. Pioglitazone attenuates atrial remodeling and vulnerability to atrial fibrillation in alloxan-induced diabetic rabbits. Cardiovasc Ther. 2017. https://doi.org/10.1111/1755-5922.12284.

68. Kume O, Takahashi N, Wakisaka O, Nagano-Torigoe Y, Teshima Y, Nakagawa M, Yufu K, Hara M, Saikawa T, Yoshimatsu H. Pioglitazone attenuates inflammatory atrial fibrosis and vulnerability to atrial fibrillation induced by pressure overload in rats. Heart Rhythm. 2011;8(2):278-85.

69. Gu J, Hu W, Liu X. Pioglitazone improves potassium channel remodeling induced by angiotensin II in atrial myocytes. Med Sci Monit Basic Res. 2014;20:153-60.

70. Gu J, Liu X, Wang QX, Guo M, Liu F, Song ZP, Zhang DD. Beneficial effects of pioglitazone on atrial structural and electrical remodeling in vitro cellular models. J Mol Cell Cardiol. 2013;65:1-8.

71. Kistamas K, Szentandrassy N, Hegyi B, Ruzsnavszky F, Vaczi K, Barandi L, Horvath B, Szebeni A, Magyar J, Banyasz T, et al. Effects of pioglitazone on cardiac ion currents and action potential morphology in canine ventricular myocytes. Eur J Pharmacol. 2013;710(1-3):10-9. 
72. Hegarty BD, Furler SM, Oakes ND, Kraegen EW, Cooney GJ. Peroxisome proliferator-activated receptor (PPAR) activation induces tissuespecific effects on fatty acid uptake and metabolism in vivo-a study using the novel PPARalpha/gamma agonist tesaglitazar. Endocrinology. 2004;145(7):3158-64.

73. Son NH, Park TS, Yamashita H, Yokoyama M, Huggins LA, Okajima K, Homma S, Szabolcs MJ, Huang LS, Goldberg IJ. Cardiomyocyte expression of PPARgamma leads to cardiac dysfunction in mice. J Clin Invest. 2007;117(10):2791-801.

74. Madrazo JA, Kelly DP. The PPAR trio: regulators of myocardial energy metabolism in health and disease. J Mol Cell Cardiol. 2008;44(6):968-75.

75. Hallsten $K$, Virtanen KA, Lonnqvist F, Janatuinen T, Turiceanu M, Ronnemaa T, Viikari J, Lehtimaki T, Knuuti J, Nuutila P. Enhancement of insulin-stimulated myocardial glucose uptake in patients with type 2 diabetes treated with rosiglitazone. Diabet Med. 2004;21(12):1280-7.

76. Lautamaki R, Airaksinen KEJ, Seppanen M, Toikka J, Luotolahti M, Ball E, Borra R, Harkonen R, lozzo P, Stewart M, et al. Rosiglitazone improves myocardial glucose uptake in patients with type 2 diabetes and coronary artery disease: a 16-week randomized, double-blind placebo-controlled study. Diabetes. 2005;54(9):2787-94.

77. Yakubu-Madus FE, Stephens TW, Johnson WT. Lipid lowering explains the insulin sensitivity enhancing effects of a thiazolidinedione, 5-(4-(2-(2-phenyl-4-oxazolyl)ethoxy)benzyl)-2,4 thiazolidinedione. Diabetes Obes Metab. 2000;2(3):155-63.

78. Racette SB, Davis AO, McGill JB, Klein S. Thiazolidinediones enhance insulin-mediated suppression of fatty acid flux in type 2 diabetes mellitus. Metabolism. 2002;51(2):169-74.

79. Goto K, Iso T, Hanaoka H, Yamaguchi A, Suga T, Hattori A, Irie Y, Shinagawa $Y$, Matsui H, Syamsunarno MR, et al. Peroxisome proliferatoractivated receptor-gamma in capillary endothelia promotes fatty acid uptake by heart during long-term fasting. J Am Heart Assoc. 2013;2(1):e004861.

80. Djouadi F, Lecarpentier Y, Hebert JL, Charron P, Bastin J, Coirault C. A potential link between peroxisome proliferator-activated receptor signalling and the pathogenesis of arrhythmogenic right ventricular cardiomyopathy. Cardiovasc Res. 2009;84(1):83-90.

81. Garcia-Gras E, Lombardi R, Giocondo MJ, Willerson JT, Schneider MD, Khoury DS, Marian AJ. Suppression of canonical Wnt/betacatenin signaling by nuclear plakoglobin recapitulates phenotype of arrhythmogenic right ventricular cardiomyopathy. J Clin Invest. 2006;116(7):2012-21.

82. Gilde AJ, van der Lee KA, Willemsen PH, Chinetti G, van der Leij FR, van der Vusse GJ, Staels B, van Bilsen M. Peroxisome proliferatoractivated receptor (PPAR) alpha and PPARbeta/delta, but not PPARgamma, modulate the expression of genes involved in cardiac lipid metabolism. Circ Res. 2003;92(5):518-24.

83. Baranowski M, Blachnio-Zabielska A, Zabielski P, Gorski J. Pioglitazone induces lipid accumulation in the rat heart despite concomitant reduction in plasma free fatty acid availability. Arch Biochem Biophys. 2008;477(1):86-91.

84. Baranowski M, Blachnio A, Zabielski P, Gorski J. Pioglitazone induces de novo ceramide synthesis in the rat heart. Prostaglandins Other Lipid Mediat. 2007:83(1-2):99-111.

85. Duan SZ, Ivashchenko CY, Russell MW, Milstone DS, Mortensen RM. Cardiomyocyte-specific knockout and agonist of peroxisome proliferator-activated receptor-gamma both induce cardiac hypertrophy in mice. Circ Res. 2005;97(4):372-9.

86. Ding G, Fu M, Qin Q, Lewis W, Kim HW, Fukai T, Bacanamwo M, Chen YE, Schneider MD, Mangelsdorf DJ, et al. Cardiac peroxisome proliferator-activated receptor gamma is essential in protecting cardiomyocytes from oxidative damage. Cardiovasc Res. 2007;76(2):269-79.

87. Son NH, Yu S, Tuinei J, Arai K, Hamai H, Homma S, Shulman Gl, Abel ED, Goldberg IJ. PPARy-induced cardiolipotoxicity in mice is ameliorated by PPARa deficiency despite increases in fatty acid oxidation. $J$ Clin Invest. 2010;120(10):3443-54

88. Vikramadithyan RK, Hirata K, Yagyu H, Hu Y, Augustus A, Homma S, Goldberg IJ. Peroxisome proliferator-activated receptor agonists modulate heart function in transgenic mice with lipotoxic cardiomyopathy. J Pharmacol Exp Ther. 2005;313(2):586-93.
89. Zhou YT, Grayburn P, Karim A, Shimabukuro M, Higa M, Baetens D, Orci L, Unger RH. Lipotoxic heart disease in obese rats: implications for human obesity. Proc Natl Acad Sci USA. 2000;97(4):1784-9.

90. Kataoka Y, Yagi N, Kokubu N, Kasahara Y, Abe M, Otsuka Y. Effect of pretreatment with pioglitazone on reperfusion injury in diabetic patients with acute myocardial infarction. Circ J. 2011;75(8):1968-74.

91. Ye $Y$, Lin $Y$, Atar $S$, Huang $M H$, Perez-Polo JR, Uretsky BF, Birnbaum $Y$. Myocardial protection by pioglitazone, atorvastatin, and their combination: mechanisms and possible interactions. Am J Physiol Heart Circ Physiol. 2006;291 (3):H1158-69.

92. Wayman NS, Hattori Y, McDonald MC, Mota-Filipe H, Cuzzocrea S, Pisano B, Chatterjee PK, Thiemermann C. Ligands of the peroxisome proliferator-activated receptors (PPAR-gamma and PPAR-alpha) reduce myocardial infarct size. FASEB J. 2002;16(9):1027-40.

93. Hu Q, Chen J, Jiang C, Liu H-F. Effect of peroxisome proliferator-activated receptor gamma agonist on heart of rabbits with acute myocardial ischemia/reperfusion injury. Asian Pac J Trop Med. 2014;7(4):271-5.

94. Ye Y, Lin Y, Manickavasagam S, Perez-Polo JR, Tieu BC, Birnbaum Y. Pioglitazone protects the myocardium against ischemia-reperfusion injury in eNOS and iNOS knockout mice. Am J Physiol Heart Circ Physiol. 2008;295(6):H2436-46.

95. Ye Y, Keyes KT, Zhang C, Perez-Polo JR, Lin Y, Birnbaum Y. The myocardial infarct size-limiting effect of sitagliptin is PKA-dependent, whereas the protective effect of pioglitazone is partially dependent on PKA. Am J Physiol Heart Circ Physiol. 2010;298(5):H1454-65.

96. Wang $\mathrm{H}$. Pioglitazone attenuates myocardial ischemia-reperfusion injury via up-regulation of ERK and COX-2. BioSci Trends. 2012. https:// doi.org/10.5582/bst.2012.v6.6.325.

97. Ahmed LA, Salem HA, Attia AS, Agha AM. Pharmacological preconditioning with nicorandil and pioglitazone attenuates myocardial ischemia/reperfusion injury in rats. Eur J Pharmacol. 2011;663(1-3):51-8.

98. Sasaki H, Ogawa K, Shimizu M, Mori C, Takatsuka H, Okazaki F, Kawai M, Taniguchi I, Mochizuki S. The Insulin sensitizer pioglitazone improves the deterioration of ischemic preconditioning in type 2 diabetes mellitus rats. Int Heart J. 2007:48(5):623-35.

99. Mittal D, Taliyan R, Sharma PL, Yadav HN. Effect of pioglitazone on the abrogated cardioprotective effect of ischemic preconditioning in hyperlipidemic rat heart. Indian J Pharmacol. 2016;48(1):59-63.

100. Zingarelli B, Hake PW, Mangeshkar P, O'Connor M, Burroughs TJ, Piraino G, Denenberg A, Wong HR. Diverse cardioprotective signaling mechanisms of peroxisome proliferator-activated receptor-gamma ligands, 15-deoxy-Delta 12,14-prostaglandin J2 and ciglitazone, in reperfusion injury: role of nuclear factor-kappaB, heat shock factor 1, and Akt. Shock. 2007;28(5):554-63.

101. Linares I, Farrokhi K, Echeverri J, Kaths JM, Kollmann D, Hamar M, Urbanellis P, Ganesh S, Adeyi OA, Yip P, et al. PPAR-gamma activation is associated with reduced liver ischemia-reperfusion injury and altered tissue-resident macrophages polarization in a mouse model. PLoS One. 2018;13(4):e0195212.

102. Ali RM, Al-Shorbagy MY, Helmy MW, El-Abhar HS. Role of Wnt4/betacatenin, Ang II/TGFbeta, ACE2, NF-kappaB, and IL-18 in attenuating renal ischemia/reperfusion-induced injury in rats treated with Vit $D$ and pioglitazone. Eur J Pharmacol. 2018;831:68-76.

103. Cuzzocrea S, Pisano B, Dugo L, lanaro A, Patel NS, Di Paola R, Genovese T, Chatterjee PK, Di Rosa M, Caputi AP, et al. Rosiglitazone and 15-deoxyDelta 12,14-prostaglandin J2, ligands of the peroxisome proliferatoractivated receptor-gamma (PPAR-gamma), reduce ischaemia/reperfusion injury of the gut. Br J Pharmacol. 2003;140(2):366-76.

104. Tao L, Wang Y, Gao E, Zhang H, Yuan Y, Lau WB, Chan L, Koch WJ, Ma XL. Adiponectin: an indispensable molecule in rosiglitazone cardioprotection following myocardial infarction. Circ Res. 2010;106(2):409-17.

105. Wang Y, Lau WB, Gao E, Tao L, Yuan Y, Li R, Wang X, Koch WJ, Ma XL. Cardiomyocyte-derived adiponectin is biologically active in protecting against myocardial ischemia-reperfusion injury. Am J Physiol Endocrinol Metab. 2010;298(3):E663-70.

106. Straznicky NE, Grima MT, Sari Cl, Eikelis N, Lambert GW, Nestel PJ, Richards K, Dixon JB, Schlaich MP, Lambert EA. Pioglitazone treatment enhances the sympathetic nervous system response to oral carbohydrate load in obese individuals with metabolic syndrome. Metabolism. 2015;64(7):797-803. 
107. Igarashi M, Jimbu Y, Hirata A, Tominaga M. Characterization of plasma brain natriuretic peptide level in patients with type 2 diabetes. Endocr J. 2005;52(3):353-62.

108. Dorkhan M, Frid A, Groop L. Differences in effects of insulin glargine or pioglitazone added to oral anti-diabetic therapy in patients with type 2 diabetes: what to add —insulin glargine or pioglitazone? Diabetes Res Clin Pract. 2008;82(3):340-5.

109. Ogawa S, Takeuchi K, Ito S. Plasma BNP levels in the treatment of type 2 diabetes with pioglitazone. J Clin Endocrinol Metab. 2003;88(8):3993-6.

110. Zhao SM, Shen LH, Li HW, Wang L, Chen H, Wang YL, Guo CY. Down-regulation of the expression of angiotensin II type 1 receptor in neonatal rat cardiac fibroblast by activation of PPARgamma signal pathway. Chin J Physiol. 2008;51(6):357-62.

111. Zanchi A, Chiolero A, Maillard M, Nussberger J, Brunner HR, Burnier M. Effects of the peroxisomal proliferator-activated receptor-gamma agonist pioglitazone on renal and hormonal responses to salt in healthy men. J Clin Endocrinol Metab. 2004;89(3):1140-5.

112. Yamamoto K, Ohki R, Lee RT, Ikeda U, Shimada K. Peroxisome proliferator-activated receptor gamma activators inhibit cardiac hypertrophy in cardiac myocytes. Circulation. 2001;104(14):1670-5.

113. Green DE, Sutliff RL, Hart CM. Is Peroxisome proliferator-activated receptor gamma (PPARY) a therapeutic target for the treatment of pulmonary hypertension? Pulm Circ. 2011;1(1):33-47.

114. Ameshima S, Golpon H, Cool CD, Chan D, Vandivier RW, Gardai SJ, Wick M, Nemenoff RA, Geraci MW, Voelkel NF. Peroxisome proliferatoractivated receptor gamma (PPARgamma) expression is decreased in pulmonary hypertension and affects endothelial cell growth. Circ Res. 2003;92(10):1162-9.

115. Kozlowska H, Baranowska-Kuczko M, Schlicker E, Kozlowski M, Kloza M, Malinowska B. Relaxation of human pulmonary arteries by PPARgamma agonists. Naunyn Schmiedebergs Arch Pharmacol. 2013;386(5):445-53.

116. Harrington LS, Moreno L, Reed A, Wort SJ, Desvergne B, Garland C, Zhao L, Mitchell JA. The PPARbeta/delta agonist GW0742 relaxes pulmonary vessels and limits right heart hypertrophy in rats with hypoxia-induced pulmonary hypertension. PLoS One. 2010;5(3):e9526.

117. Oishi PE, Sharma S, Datar SA, Kumar S, Aggarwal S, Lu Q, Raff G, Azakie A, Hsu JH, Sajti E, et al. Rosiglitazone preserves pulmonary vascular function in lambs with increased pulmonary blood flow. Pediatr Res. 2013;73(1):54-61.

118. Kim EK, Lee JH, Oh YM, Lee YS, Lee SD. Rosiglitazone attenuates hypoxia-induced pulmonary arterial hypertension in rats. Respirology. 2010;15(4):659-68.

119. Crossno JT Jr, Garat CV, Reusch JE, Morris KG, Dempsey EC, McMurtry IF, Stenmark KR, Klemm DJ. Rosiglitazone attenuates hypoxia-induced pulmonary arterial remodeling. Am J Physiol Lung Cell Mol Physiol. 2007;292(4):L885-97.

120. Nisbet RE, Bland JM, Kleinhenz DJ, Mitchell PO, Walp ER, Sutliff RL, Hart CM. Rosiglitazone attenuates chronic hypoxia-induced pulmonary hypertension in a mouse model. Am J Respir Cell Mol Biol. 2010;42(4):482-90.

121. Chaudhry A, Carthan KA, Kang BY, Calvert J, Sutliff RL, Michael Hart C. PPARgamma attenuates hypoxia-induced hypertrophic transcriptional pathways in the heart. Pulm Circ. 2017;7(1):98-107.

122. Behringer $A$, Trappiel $M$, Berghausen $E M$, Ten Freyhaus $H$, Wellnhofer $E$, Odenthal M, Blaschke F, Er F, Gassanov N, Rosenkranz S, et al. Pioglitazone alleviates cardiac and vascular remodelling and improves survival in monocrotaline induced pulmonary arterial hypertension. Naunyn Schmiedebergs Arch Pharmacol. 2016:389(4):369-79.

123. Chun HJ, Bonnet S, Chan SY. Translational advances in the field of pulmonary hypertension. Translating MicroRNA biology in pulmonary hypertension. It will take more than "miR" words. Am J Respir Crit Care Med. 2017;195(2):167-78.

124. Hansmann G, Wagner RA, Schellong S, Perez VA, Urashima T, Wang L, Sheikh AY, Suen RS, Stewart DJ, Rabinovitch M. Pulmonary arterial hypertension is linked to insulin resistance and reversed by peroxisome proliferator-activated receptor-gamma activation. Circulation. 2007;115(10):1275-84

125. Legchenko E, Chouvarine P, Borchert P, Fernandez-Gonzalez A, Snay E, Meier M, Maegel L, Mitsialis SA, Rog-Zielinska EA, Kourembanas S, et al. PPARgamma agonist pioglitazone reverses pulmonary hypertension and prevents right heart failure via fatty acid oxidation. Sci Transl Med. 2018. https://doi.org/10.1126/scitranslmed.aao0303.

126. Marder W, Khalatbari S, Myles JD, Hench R, Lustig S, Yalavarthi S, Parameswaran A, Brook RD, Kaplan MJ. The peroxisome proliferator activated receptor-gamma pioglitazone improves vascular function and decreases disease activity in patients with rheumatoid arthritis. J Am Heart Assoc. 2013:2(6):e000441.

127. Mazzone T, Meyer PM, Feinstein SB, Davidson MH, Kondos GT, D'Agostino RB Sr, Perez A, Provost JC, Haffner SM. Effect of pioglitazone compared with glimepiride on carotid intima-media thickness in type 2 diabetes: a randomized trial. JAMA. 2006;296(21):2572-81.

128. Skochko OV, Kaidashev IP. Effect of pioglitazone on insulin resistance, progression of atherosclerosis and clinical course of coronary heart disease. Wiad Lek. 2017:70(5):881-90.

129. Koshiyama H, Shimono D, Kuwamura N, Minamikawa J, Nakamura Y. Rapid communication: inhibitory effect of pioglitazone on carotid arterial wall thickness in type 2 diabetes. J Clin Endocrinol Metab. 2001;86(7):3452-6.

130. Choo EH, Han EJ, Kim CJ, Kim SH, O JH, Chang K, Seung KB. Effect of pioglitazone in combination with moderate dose statin on atherosclerotic inflammation: randomized controlled clinical trial using serial FDG-PET/CT. Korean Circ J. 2018:48(7):591-601.

131. Mizoguchi M, Tahara N, Tahara A, Nitta Y, Kodama N, Oba T, Mawatari K, Yasukawa H, Kaida H, Ishibashi M, et al. Pioglitazone attenuates atherosclerotic plaque inflammation in patients with impaired glucose tolerance or diabetes a prospective, randomized, comparator-controlled study using serial FDG PET/CT imaging study of carotid artery and ascending aorta. JACC Cardiovasc Imaging. 2011;4(10):1110-8.

132. Hong SJ, Choi SC, Cho JY, Joo HJ, Park JH, Yu CW, Lim DS. Pioglitazone increases circulating microRNA-24 with decrease in coronary neointimal hyperplasia in type 2 diabetic patients-optical coherence tomography analysis. Circ J. 2015;79(4):880-8.

133. Marx N, Wohrle J, Nusser T, Walcher D, Rinker A, Hombach V, Koenig W, Hoher M. Pioglitazone reduces neointima volume after coronary stent implantation: a randomized, placebo-controlled, double-blind trial in nondiabetic patients. Circulation. 2005;112(18):2792-8.

134. Hong SJ, Kim ST, Kim TJ, Kim EO, Ahn CM, Park JH, Kim JS, Lee KM, Lim DS. Cellular and molecular changes associated with inhibitory effect of pioglitazone on neointimal growth in patients with type 2 diabetes after zotarolimus-eluting stent implantation. Arterioscler Thromb Vasc Biol. 2010;30(12):2655-65.

135. Nissen SE, Nicholls SJ, Wolski K, Nesto R, Kupfer S, Perez A, Jure H, De Larochelliere R, Staniloae CS, Mavromatis K, et al. Comparison of pioglitazone vs glimepiride on progression of coronary atherosclerosis in patients with type 2 diabetes: the PERISCOPE randomized controlled trial. JAMA. 2008:299(13):1561-73.

136. Takagi T, Okura H, Kobayashi Y, Kataoka T, Taguchi H, Toda I, Tamita K, Yamamuro A, Sakanoue Y, Ito A, et al. A prospective, multicenter, randomized trial to assess efficacy of pioglitazone on in-stent neointimal suppression in type 2 diabetes: POPPS (Prevention of In-Stent Neointimal Proliferation by Pioglitazone Study). JACC Cardiovasc Interv. 2009;2(6):524-31.

137. Patel D, Walitt B, Lindsay J, Wilensky RL. Role of pioglitazone in the prevention of restenosis and need for revascularization after baremetal stent implantation: a meta-analysis. JACC Cardiovasc Interv. 2011;4(3):353-60

138. Lee HW, Lee HC, Kim BW, Yang MJ, Park JS, Oh JH, Choi JH, Cha KS, Hong $\mathrm{TJ}$, Kim SP, et al. Effects of low dose pioglitazone on restenosis and coronary atherosclerosis in diabetic patients undergoing drug eluting stent implantation. Yonsei Med J. 2013;54(6):1313-20.

139. Zhang MD, Zhang YH, Zhu EJ, Qiao SB, Lv SZ, Zhao QM. Effect of pioglitazone on in-stent restenosis after coronary drug-eluting stent implantation: a meta-analysis of randomized controlled trials. PLoS One. 2014;9(10):e109614

140. Zhao SJ, Zhong ZS, Qi GX, Shi LY, Chen L, Tian W. Effect of pioglitazone in preventing in-stent restenosis after percutaneous coronary intervention in patients with type 2 diabetes: a meta-analysis. PLoS One. 2016;11(5):e0155273.

141. Schneider F, Vossler S, Franke S, Bar F, Konrad T. Impact of insulin sensitivity treatment with pioglitazone on endothelial function in 
non-diabetic patients with arterial hypertension. Int J Clin Pharmacol Ther. 2009:47(5):311-20.

142. Papathanassiou K, Naka KK, Kazakos N, Kanioglou C, Makriyiannis D, Pappas K, Katsouras CS, Liveris K, Kolettis T, Tsatsoulis A, et al. Pioglitazone vs glimepiride: differential effects on vascular endothelial function in patients with type 2 diabetes. Atherosclerosis. 2009;205(1):221-6.

143. Rizza S, Cardellini M, Porzio O, Pecchioli C, Savo A, Cardolini I, Senese N, Lauro D, Sbraccia P, Lauro R, et al. Pioglitazone improves endothelial and adipose tissue dysfunction in pre-diabetic CAD subjects. Atherosclerosis. 2011;215(1):180-3.

144. Quinn CE, Lockhart CJ, Hamilton PK, Loughrey CM, McVeigh GE. Effect of pioglitazone on endothelial function in impaired glucose tolerance. Diabetes Obes Metab. 2010;12(8):709-15.

145. Stojanovic M, Prostran M, Radenkovic M. Thiazolidinediones improve flow-mediated dilation: a meta-analysis of randomized clinical trials. Eur J Clin Pharmacol. 2016;72(4):385-98.

146. Sourij H, Zweiker R, Wascher TC. Effects of pioglitazone on endothelial function, insulin sensitivity, and glucose control in subjects with coronary artery disease and new-onset type 2 diabetes. Diabetes Care. 2006;29(5):1039-45.

147. Martens FM, Visseren FL, de Koning EJ, Rabelink TJ. Short-term pioglitazone treatment improves vascular function irrespective of metabolic changes in patients with type 2 diabetes. J Cardiovasc Pharmacol. 2005:46(6):773-8.

148. Davidson M, Meyer PM, Haffner S, Feinstein S, D'Agostino R Sr, Kondos GT, Perez A, Chen Z, Mazzone T. Increased high-density lipoprotein cholesterol predicts the pioglitazone-mediated reduction of carotid intima-media thickness progression in patients with type 2 diabetes mellitus. Circulation. 2008;117(16):2123-30

149. Panigrahy D, Singer S, Shen LQ, Butterfield CE, Freedman DA, Chen EJ, Moses MA, Kilroy S, Duensing S, Fletcher C, et al. PPARgamma ligands inhibit primary tumor growth and metastasis by inhibiting angiogenesis. J Clin Invest. 2002;110(7):923-32.

150. Hamblin M, Chang L, Fan Y, Zhang J, Chen YE. PPARs and the cardiovascular system. Antioxid Redox Signal. 2009;11(6):1415-52.

151. Zhu J, Zhao Y, Yu L, Wang M, Li Q, Xu S. Pioglitazone restores the homocysteineimpaired function of endothelial progenitor cells via the inhibition of the protein kinase C/NADPH oxidase pathway. Mol Med Rep. 2018;18(2):1637-43.

152. Calvier L, Chouvarine P, Legchenko E, Hoffmann N, Geldner J, Borchert P, Jonigk D, Mozes MM, Hansmann G. PPARgamma links BMP2 and TGFbeta1 Pathways in vascular smooth muscle cells, regulating cell proliferation and glucose metabolism. Cell Metab. 2017;25(5):1118-34 e7.

153. Sakamoto A, Higashikuni Y, Hongo M, Imai Y, Koike K, Nagai R, Komuro I, Ishizaka N. Pioglitazone reduces vascular lipid accumulation in angiotensin ii-induced hypertensive rat. J Atheroscler Thromb. 2015;22(12):1225-34.

154. Marx N, Walcher D, Ivanova N, Rautzenberg K, Jung A, Friedl R, Hombach V, de Caterina R, Basta G, Wautier MP, et al. Thiazolidinediones reduce endothelial expression of receptors for advanced glycation end products. Diabetes. 2004;53(10):2662-8.

155. Perez-Giron JV, Palacios R, Martin A, Hernanz R, Aguado A, MartinezRevelles S, Barrus MT, Salaices M, Alonso MJ. Pioglitazone reduces angiotensin II-induced COX-2 expression through inhibition of ROS production and ET-1 transcription in vascular cells from spontaneously hypertensive rats. Am J Physiol Heart Circ Physiol. 2014;306(11):H1582-93.

156. Kvandova M, Barancik M, Balis P, Puzserova A, Majzunova M, Dovinova I. The peroxisome proliferator-activated receptor gamma agonist pioglitazone improves nitric oxide availability, renin-angiotensin system and aberrant redox regulation in the kidney of pre-hypertensive rats. $J$ Physiol Pharmacol. 2018. https://doi.org/10.26402/jpp.2018.2.09.

157. Smith SR, De Jonge L, Volaufova J, Li Y, Xie H, Bray GA. Effect of pioglitazone on body composition and energy expenditure: a randomized controlled trial. Metabolism. 2005;54(1):24-32.

158. Bogacka I, Xie H, Bray GA, Smith SR. The effect of pioglitazone on peroxisome proliferator-activated receptor-gamma target genes related to lipid storage in vivo. Diabetes Care. 2004;27(7):1660-7.

159. Zanchi A, Tappy L, Le KA, Bortolotti M, Theumann N, Halabi G, Gauthier T, Mathieu C, Tremblay S, Bertrand PC, et al. Pioglitazone improves fat distribution, the adipokine profile and hepatic insulin sensitivity in non-diabetic end-stage renal disease subjects on maintenance dialysis: a randomized cross-over pilot study. PLoS One. 2014;9(10):e109134.

160. Kodama N, Tahara N, Tahara A, Honda A, Nitta Y, Mizoguchi M, Kaida $\mathrm{H}$, Ishibashi $\mathrm{M}$, Abe $\mathrm{T}$, Ikeda $\mathrm{H}$, et al. Effects of pioglitazone on visceral fat metabolic activity in impaired glucose tolerance or type 2 diabetes mellitus. J Clin Endocrinol Metab. 2013:98(11):4438-45.

161. Teranishi T, Ohara T, Maeda K, Zenibayashi M, Kouyama K, Hirota Y, Kawamitsu H, Fujii M, Sugimura K, Kasuga M. Effects of pioglitazone and metformin on intracellular lipid content in liver and skeletal muscle of individuals with type 2 diabetes mellitus. Metabolism. 2007:56(10):1418-24.

162. Shadid S, Jensen MD. Effects of pioglitazone versus diet and exercise on metabolic health and fat distribution in upper body obesity. Diabetes Care. 2003:26(11):3148-52.

163. de Souza CJ, Eckhardt M, Gagen K, Dong M, Chen W, Laurent D, Burkey $B F$. Effects of pioglitazone on adipose tissue remodeling within the setting of obesity and insulin resistance. Diabetes. 2001;50(8):1863-71.

164. Boden G, Cheung P, Mozzoli M, Fried SK. Effect of thiazolidinediones on glucose and fatty acid metabolism in patients with type 2 diabetes. Metabolism. 2003;52(6):753-9.

165. McLaughlin TM, Liu T, Yee G, Abbasi F, Lamendola C, Reaven GM, Tsao P, Cushman SW, Sherman A. Pioglitazone increases the proportion of small cells in human abdominal subcutaneous adipose tissue. Obesity. 2010;18(5):926-31.

166. Hammarstedt A, Sopasakis VR, Gogg S, Jansson PA, Smith U. Improved insulin sensitivity and adipose tissue dysregulation after short-term treatment with pioglitazone in non-diabetic, insulin-resistant subjects. Diabetologia. 2005:48(1):96-104.

167. Xie X, Sinha S, Yi Z, Langlais PR, Madan M, Bowen BP, Willis W, Meyer C. Role of adipocyte mitochondria in inflammation, lipemia and insulin sensitivity in humans: effects of pioglitazone treatment. Int J Obes. 2017. https://doi.org/10.1038/ijo.2017.192.

168. Bogacka I, Xie H, Bray GA, Smith SR. Pioglitazone induces mitochondrial biogenesis in human subcutaneous adipose tissue in vivo. Diabetes. 2005;54(5):1392-9.

169. Derosa G, Cicero AF, D'Angelo A, Gaddi A, Ciccarelli L, Piccinni MN, Salvadeo SA, Pricolo F, Ferrari I, Gravina A, et al. Effects of 1 year of treatment with pioglitazone or rosiglitazone added to glimepiride on lipoprotein (a) and homocysteine concentrations in patients with type 2 diabetes mellitus and metabolic syndrome: a multicenter, randomized, double-blind, controlled clinical trial. Clin Ther. 2006:28(5):679-88.

170. Nakano K, Hasegawa G, Fukui M, Yamasaki M, Ishihara K, Takashima T, Kitagawa Y, Fujinami A, Ohta M, Hara H, et al. Effect of pioglitazone on various parameters of insulin resistance including lipoprotein subclass according to particle size by a gel-permeation high-performance liquid chromatography in newly diagnosed patients with type 2 diabetes. Endocr J. 2010;57(5):423-30.

171. Goldberg RB, Kendall DM, Deeg MA, Buse JB, Zagar AJ, Pinaire JA, Tan MH, Khan MA, Perez AT, Jacober SJ. A Comparison of lipid and glycemic effects of pioglitazone and rosiglitazone in patients with type 2 diabetes and dyslipidemia. Diabetes Care. 2005;28(7):1547-54.

172. Abdul-Ghani M, Jayyous A, Asaad N, Helmy S, Al-Suwaidi J. Pioglitazone and cardiovascular risk in T2DM patients: is it good for all? Ann Transl Med. 2018;6(10):192.

173. Derosa G, Fogari E, Cicero AF, D'Angelo A, Ciccarelli L, Piccinni MN, Pricolo F, Salvadeo SA, Gravina A, Ferrari I, et al. Blood pressure control and inflammatory markers in type 2 diabetic patients treated with pioglitazone or rosiglitazone and metformin. Hypertens Res. 2007;30(5):387-94.

174. Schondorf T, Forst T, Hohberg C, Pahler S, Link C, Roth W, Pfutzner A, Lubben G, Link C, Pfutzner A. The IRIS III study: pioglitazone improves metabolic control and blood pressure in patients with type 2 diabetes without increasing body weight. Diabetes Obes Metab. 2007;9(1):132-3.

175. Abe M, Okada K, Kikuchi F, Matsumoto K. Clinical investigation of the effects of pioglitazone on the improvement of insulin resistance and blood pressure in type 2-diabetic patients undergoing hemodialysis. Clin Nephrol. 2008;70(3):220-8.

176. Kashiwagi Y, Mizuno Y, Harada E, Shono M, Morita S, Yoshimura M, Yano $\mathrm{M}$, Yasue $\mathrm{H}$. Suppression of primary aldosteronism and resistant 
hypertension by the peroxisome proliferator-activated receptor gamma agonist pioglitazone. Am J Med Sci. 2013;345(6):497-500.

177. Yang SC, Tseng HL, Shieh KR. Circadian-clock system in mouse liver affected by insulin resistance. Chronobiol Int. 2013;30(6):796-810.

178. Ando H, Yanagihara H, Hayashi Y, Obi Y, Tsuruoka S, Takamura T, Kaneko S, Fujimura A. Rhythmic messenger ribonucleic acid expression of clock genes and adipocytokines in mouse visceral adipose tissue. Endocrinology. 2005;146(12):5631-6.

179. Anan F, Masaki T, Fukunaga N, Teshima Y, Iwao T, Kaneda K, Umeno Y, Okada K, Wakasugi K, Yonemochi H, et al. Pioglitazone shift circadian rhythm of blood pressure from non-dipper to dipper type in type 2 diabetes mellitus. Eur J Clin Invest. 2007;37(9):709-14.

180. Negro R, Dazzi D, Hassan H, Pezzarossa A. Pioglitazone reduces blood pressure in non-dipping diabetic patients. Minerva Endocrinol. 2004;29(1):11-7.

181. Gianiorio FE, Casu M, Patrone V, Egan CG, Murialdo G. Effect of pioglitazone on cardiac sympathovagal modulation in patients with type 2 diabetes. Acta Diabetol. 2011;48(4):283-90.

182. Usuda D, Kanda T. Peroxisome proliferator-activated receptors for hypertension. World J Cardiol. 2014;6(8):744-54.

183. Dobrian AD, Schriver SD, Khraibi AA, Prewitt RL. Pioglitazone prevents hypertension and reduces oxidative stress in diet-induced obesity. Hypertension. 2004;43(1):48-56.

184. Nakamoto M, Ohya Y, Shinzato T, Mano R, Yamazato M, Sakima A, Takishita S. Pioglitazone, a thiazolidinedione derivative, attenuates left ventricular hypertrophy and fibrosis in salt-sensitive hypertension. Hypertens Res. 2008;31(2):353-61.

185. Sakamoto A, Hongo M, Saito K, Nagai R, Ishizaka N. Reduction of renal lipid content and proteinuria by a PPAR-gamma agonist in a rat model of angiotensin II-induced hypertension. Eur J Pharmacol. 2012;682(1-3):131-6.

186. Lan LF, Zheng L, Yang X, Ji XT, Fan YH, Zeng JS. Peroxisome proliferatoractivated receptor-gamma agonist pioglitazone ameliorates white matter lesion and cognitive impairment in hypertensive rats. CNS Neurosci Ther. 2015;21(5):410-6.

187. Song J, Walsh MF, Igwe R, Ram JL, Barazi M, Dominguez LJ, Sowers JR. Troglitazone reduces contraction by inhibition of vascular smooth muscle cell Ca2+ currents and not endothelial nitric oxide production. Diabetes. 1997;46(4):659-64.

188. Goud C, Pitt B, Webb RC, Richey JM. Synergistic actions of insulin and troglitazone on contractility in endothelium-denuded rat aortic rings. Am J Physiol. 1998;275(5 Pt 1):E882-7.

189. Wang N, Yang G, Jia Z, Zhang H, Aoyagi T, Soodvilai S, Symons JD, Schnermann JB, Gonzalez FJ, Litwin SE, et al. Vascular PPARgamma controls circadian variation in blood pressure and heart rate through Bmal1. Cell Metab. 2008:8(6):482-91.

190. Xie Z, Su W, Liu S, Zhao G, Esser K, Schroder EA, Lefta M, Stauss HM, Guo Z, Gong MC. Smooth-muscle BMAL1 participates in blood pressure circadian rhythm regulation. J Clin Invest. 2015;125(1):324-36.

191. Hollenberg NK. Considerations for management of fluid dynamic issues associated with thiazolidinediones. Am J Med. 2003;115(Suppl 8A):111S-5S.

192. Staels B. Fluid retention mediated by renal PPARgamma. Cell Metab. 2005;2(2):77-8.

193. Baba T, Shimada K, Neugebauer S, Yamada D, Hashimoto S, Watanabe T. The oral insulin sensitizer, thiazolidinedione, increases plasma vascular endothelial growth factor in type 2 diabetic patients. Diabetes Care. 2001;24(5):953-4.

194. Yang T. Kidney-specific gene targeting: insight into thiazolidinedioneinduced fluid retention. Nephrology. 2006;1 1(3):201-6.

195. Pegg K, Zhang J, Pollock C, Saad S. Combined effects of PPAR gamma agonists and epidermal growth factor receptor inhibitors in human proximal tubule cells. PPAR Res. 2013;2013:982462.

196. Saad S, Zhang J, Yong R, Yaghobian D, Wong MG, Kelly DJ, Chen XM, Pollock CA. Role of the EGF receptor in PPARgamma-mediated sodium and water transport in human proximal tubule cells. Diabetologia. 2013;56(5):1174-82.

197. Saad S, Agapiou DJ, Chen XM, Stevens V, Pollock CA. The role of Sgk-1 in the upregulation of transport proteins by PPAR-\{gamma\} agonists in human proximal tubule cells. Nephrol Dial Transplant. 2009;24(4):1130-41

198. Seki G, Endo Y, Suzuki M, Yamada H, Horita S, Fujita T. Role of renal proximal tubule transport in thiazolidinedione-induced volume expansion. World J Nephrol. 2012;1(5):146-50

199. Horita S, Seki G, Yamada H, Suzuki M, Koike K, Fujita T. Insulin resistance, obesity, hypertension, and renal sodium transport. Int J Hypertens. 2011;2011:391762.

200. Song J, Knepper MA, Hu X, Verbalis JG, Ecelbarger CA. Rosiglitazone activates renal sodium- and water-reabsorptive pathways and lowers blood pressure in normal rats. J Pharmacol Exp Ther 2004;308(2):426-33.

201. Yoshioka K, Wakino S, Homma K, Kanda T, Tatematsu S, Hasegawa K, Sugano N, Ito O, Omata K, Saruta T, et al. Renal cytochrome P450 as a determinant of impaired natriuresis by PPAR-gamma ligands in ovariectomized obese rats. Obesity. 2008;16(5):965-71.

202. Yang B, Clifton LG, McNulty JA, Chen L, Brown KK, Baer PG. Effects of a PPARgamma agonist, GI262570, on renal filtration fraction and nitric oxide level in conscious rats. J Cardiovasc Pharmacol. 2003:42(3):436-41.

203. Guan Y, Hao C, Cha DR, Rao R, Lu W, Kohan DE, Magnuson MA, Redha $R$, Zhang Y, Breyer MD. Thiazolidinediones expand body fluid volume through PPARgamma stimulation of ENaC-mediated renal salt absorption. Nat Med. 2005;11(8):861-6.

204. Muto S, Miyata Y, Imai M, Asano Y. Troglitazone stimulates basolateral rheogenic $\mathrm{Na}+/ \mathrm{HCO}$ - cotransport activity in rabbit proximal straight tubules. Exp Nephrol. 2001;9(3):191-7.

205. Riazi S, Khan O, Tiwari S, Hu X, Ecelbarger CA. Rosiglitazone regulates $\mathrm{ENaC}$ and $\mathrm{Na}-\mathrm{K}-2 \mathrm{Cl}$ cotransporter (NKCC2) abundance in the obese Zucker rat. Am J Nephrol. 2006;26(3):245-57.

206. DeFronzo RA, Chilton R, Norton L, Clarke G, Ryder RE, Abdul-Ghani M. Revitalization of pioglitazone: the optimum agent to be combined with a sodium-glucose co-transporter-2 inhibitor. Diabetes Obes Metab. 2016;18(5):454-62.

207. Abdul-Ghani M, DeFronzo RA, Del Prato S, Chilton R, Singh R, Ryder REJ. Cardiovascular disease and type 2 diabetes: has the dawn of a new era arrived? Diabetes Care. 2017:40(7):813-20.

\section{Publisher's Note}

Springer Nature remains neutral with regard to jurisdictional claims in published maps and institutional affiliations. 